\title{
Mercury sources and transformations in a man-perturbed tidal estuary; the Sinnamary Estuary, French Guiana
}

\author{
B. Muresan ${ }^{1}$, D. Cossa ${ }^{1, *}$, M. Coquery ${ }^{2}$, S. Richard ${ }^{3}$
}

\author{
${ }^{1}$ Institut français de recherche pour l'exploitation durable de la mer (IFREMER), BP 21105, F.44311 Nantes \\ cedex 3, France (EU) \\ ${ }^{2}$ Centre national du machinisme agricole, du génie rural et des eaux et forêts (CEMAGREF), BP 220, F.69336 \\ Lyon cedex 9, France (EU) \\ ${ }^{3}$ Laboratoire de recherche en environnement barrage de Petit-Saut (HYDRECO), BP 823, F.97388 Kourou, \\ French Guiana (EU) \\ *: Corresponding author : D. Cossa, email address : Daniel.Cossa@ifremer.fr
}

\begin{abstract}
:
The distribution, partition and speciation of mercury $(\mathrm{Hg})$ were studied along the redox gradient of an anthropogenically perturbed tropical estuary, the Sinnamary Estuary in French Guiana. This system is a partially mixed estuary characterized by an anoxic freshwater end-member, while the marine end member consists of the Amazon Plume.

The set up of an artificial oxygenation system in the anoxic freshwater end-member generates sharp gradients of major chemical species (iron, sulfides, etc.) coupled with intense organic matter (OM) turnover. The coexistence of oxygenated waters and dissolved sulfides in an organic rich environment depicts the Upper Sinnamary Estuary (USE: part of Sinnamary Estuary under the tidal influence but upstream of the salt intrusion) as a potential site for $\mathrm{Hg}$ methylation. The concentrations of all mercurial species (HgT) in the unfiltered samples (HgTUNF), in the dissolved (HgTD) and particulate (HgTP) phases of the USE average $11 \pm 3,6 \pm 2$ and $5 \pm 3$ (i.e. $600 \pm 200 \mathrm{pmol} \mathrm{g}^{-1}$ ) pmol L $\mathrm{p}^{-1}$ respectively. Average concentrations of monomethylmercury (MMHg) in the unfiltered (MMHgUNF), dissolved (MMHgD) and particulate (MMHgP) phases were $3.7 \pm 1.0,2.0 \pm 0.9$ and $1.8 \pm 1.2$ (i.e. 220 $\left.\pm 130 \mathrm{pmol} \mathrm{g}^{-1}\right) \mathrm{pmol} \mathrm{L}^{-1}$ respectively. Water oxygenation and sulfides concentrations emerged to play a critical role in controlling MMHg levels. Additionally, iron cycling, acid-base mechanisms, and edoxdependent processes were involved in the $\mathrm{MMHg}$ partitioning between phases. Overall, the USE constitutes a biogeochemical reactor that gathers partitioning and methylation processes. The permanent $\mathrm{MMHg}$ inputs from the anoxic freshwater end-member combined with the intense endogenous $\mathrm{Hg}$ methylation ensures high $\mathrm{MMHg}$ levels in both dissolved and particulate phases. To illustrate, the USE exports $60 \pm 20 \%$ more MMHgUNF than it imports: $5.5 \pm 0.7$ vs. $3.5 \pm 1.2 \mathrm{~kg} \mathrm{y}^{-1}$.
\end{abstract}

Keywords: Estuary; Reservoir; Mercury; Redox; Speciation; Partitioning 


\section{Introduction}

Estuaries define transitional environments of active biogeochemical transformations. The chemical and physical gradients characterizing these continent-ocean interfaces affect the cycle of numerous metals (Boyle et al., 1977; Mantoura et al., 1978; Sholkovitz et al., 1978; Boughriet et al., 1992; Mota et al., 2005). Among those, mercury $(\mathrm{Hg})$ transformations are particularly important. Its multiple valence states and chemical associations (with thiol or sulfide groups) are common in natural conditions (Baeyens and Leemarkers, 1998; Dyrssen and Wedborg, 1991; Cossa and Gobeil, 1996; Coquery et al., 1997). The $\mathrm{Hg}$ cycle also involves biologically mediated processes such as reduction / oxidation or methylation / demethylation (e.g., Choi et al., 1994; Heyes et al., 2006; Whalin et al., 2007).

In the aquatic environment, monomethylmercury $(\mathrm{MMHg})$ is the form of greatest concern since it collects in organisms (bioaccumulates) and concentrates up food chains (biomagnifies). MMHg concentration maxima are generally correlated with redox transition zones containing sulfate-reducing bacteria (SRB) which are thought to be the key methylating agents (e.g., Jensen and Jernelov, 1969; Gilmour et al., 1992; King et al., 1999; Benoit et al., 2003; Bisinoti and Jardim, 2005). Exploration of redox dependant and biologically driven mechanisms is of great significance for predicting the distribution and speciation of $\mathrm{Hg}$ inputs to freshwater lakes and reservoirs, including coastal sediments, the ocean, the atmosphere, and their living organisms.

In temperate and cold regions, the potential methylation of inorganic $\mathrm{Hg}$ to $\mathrm{MMHg}$ has given rise to numerous studies (e.g. Compeau and Bartha, 1984, 1985; Mason et al., 1993; Benoit et al., 1998; Mason et al., 1999; Sunderland et al., 2004; Rodriguez et al., 2004; Stoichev et al., 2006). In contrast, $\mathrm{Hg}$ behavior in tropical estuaries is very poorly known (Guimaraes et al., 2000a and b; Roulet et al., 1998a, 2000; Sergio et al., 2006). The paucity of data is all the more manifest when considering tropical estuaries that undergo hypolimnetic discharges from a stratified man-made lake. Consider, we dammed over half of the world's streams at unprecedented rates of one per hour, and at unprecedented scales of over 45,000 dams more than $15 \mathrm{~m}$ high (World Commission on Dams, 2000). Almost all of these dams display periods of stratification and development of an anoxic hypolimnion in the deepest part of their reservoirs (International Commission on Large Dams, 2003). Stratified reservoirs exhibit a great potential for increased $\mathrm{MMHg}$ production in the hypolimnion of their water column and/or in the anoxic zone of their sediments (Parks et al., 1989; Bloom and Effler, 1990; Watras et al., 1994; Jacobs et al., 1995). Discharged waters also contain high levels of organic matters (OM) and hydrogen sulfides $\left(\mathrm{\Sigma}_{2} \mathrm{~S}\right)$. Build up of favorable methylating conditions (intense microbial activity coupled with reduced water oxygenation) downstream of the reservoirs supports the formation of endogenous $\mathrm{MMHg}$. Accordingly, the environmental impact of the rivers, estuaries and other water bodies that undergo hypolimnetic discharges is far from negligible.

The main goal of this paper is to test the hypothesis offered by Benoit et al. (2003) stating that the extent of $\mathrm{Hg}$ methylation would be a function of sulfides levels, as this is the ligand controlling $\mathrm{Hg}$ speciation in solution in low oxygen zones where SRB are active. Furthermore, the same authors pointed to the difficulty to ascertain from the field data which among $\mathrm{Fe}, \mathrm{S}$ and $\mathrm{OM}$ is the dominant solid phase binding $\mathrm{Hg}$ in the environment. Therefore, we probed the magnitude of the effect of these species on the $\mathrm{Hg}$ dynamics between the dissolved and the particulate phases. To reach this goal, we appraised the methylation potential of a tropical water bodies that undergo hypolimnetic discharges. We addressed the following questions (i) What is the role of hypolimnetic discharges on the estuarine $\mathrm{Hg}$ cycle? (ii) Is there a redistribution of $\mathrm{Hg}$ species between the dissolved and particulate phase? (iii) What are the roles of $\mathrm{OM}$ and iron in the redistribution of $\mathrm{Hg}$ between phases? (iv) What is the importance of the in situ methylation with respect to external sources of $\mathrm{MMHg}$ ? and (v) Which parameters and/or processes govern the production of $\mathrm{MMHg}$ in these aquatic environment? We address these questions in the Sinnamary Estuary (French Guiana, Fig. 1). An estuary that undergoes permanent hypolimnetic discharges from the hydroelectric reservoir of Petit-Saut.

\section{The Sinnamary Estuary}

The Sinnamary Estuary spans over $70 \mathrm{~km}$ from the dam of the artificial reservoir of Petit-Saut $\left(5^{\circ} 04^{\prime}\right.$ North, $53^{\circ} 03^{\prime}$ West) to the Atlantic Ocean (Fig. 1). Some minor creeks contribute to the total water discharge to the ocean. The residence time of waters is between 24 and 48 hours (HYDRECO data). The tidal amplitude ranges from a few centimeters near the dam to a maximum close to $3 \mathrm{~m}$ at the 
mouth of the estuary during spring tide (Amouroux, 2003). However, the salt intrusion never exceeds a few $\mathrm{km}$ beyond the village of Sinnamary. We called the freshwater portion the Upper Sinnamary Estuary (USE) and the saline portion the Lower Sinnamary Estuary (LES). The USE is circa $50 \mathrm{~m}$ width, its depth at mid-width varies between 5 and $10 \mathrm{~m}$ and its course displays an overall slope of $0.03 \mathrm{~m} \mathrm{~km}^{-1}$. Except for local falls (named "Sauts"), where the water stream was turbulent, the circulation pattern of the USE was characterized by a near-laminar flow regime. In its water column, the high volumes of hypolimnetic discharges and the low-depth water bottom set the measured parameters stable with depth.

Between 1989 and 1994, the construction of the hydroelectric dam of Petit-Saut took place. The filling of the reservoir generated major modifications in the water chemistry of the USE. Initially, the waters were warm, acidic, only slightly conductive, oxygenated, nutrient poor and relatively homogenous (Horeau et al., 1998). As a result of the Petit-Saut reservoir stratification, the USE started to convey mineralized waters related to elevated amounts of OM and reduced species. To maintain dissolved oxygen concentrations that are compatible with aquatic life, an aeration system was set up in the outflow from the dam turbines. Nonetheless, strong oxygen consumption remained apparent within the estuary (up to $0.1 \mathrm{mmol} \mathrm{L}^{-1}$ of 5-day biological oxygen demand according to Richard et al., 1997).

\section{Material and Methods}

\subsection{Sampling campaigns}

Samples from the Sinnamary Estuary were collected during five campaigns that took place in MarchApril 2003, January-February 2004, May-June 2004, November-December 2004 and February-March 2005. The sampling campaigns, designated as Matoutou 1, 2, 3, 4 and 5, reflected the major seasons of the guianese climate (Tab. 1). Those are the short wet season (from November to February), the short dry season (from February to April), the long wet season (April to July) and the long dry season (from July to November). During the Matoutou campaigns, from $200 \mathrm{~m}$ downstream of the dam $\left(5^{\circ} 04.01^{\prime} \mathrm{N}-53^{\circ} 03.26^{\prime} \mathrm{W}\right)$ to the saline gradient $\left(5^{\circ} 26.03^{\prime} \mathrm{N}-52^{\circ} 59.62^{\prime} \mathrm{W}\right)$, the USE was invariably sampled at the same eight stations: Pas., Ker., Cha., Ven., Bra., Com., Deg. and Sin. (i.e., Passerelle, Kerenrock, Chapeau, Venus, Bravo, Combi, Degrad and the village of Sinnamary, respectively) (Fig. 1). The Sin. station was the geographical reference point used to distinguish the USE from the LES. The locations of the sampling stations were chosen to provide a comprehensive assessment of $\mathrm{Hg}$ species transformations in the USE with respect to important ancillary parameters such as OM and dissolved iron.

Additional sampling for water took place on a weekly basis between March 2003 and December 2004 at the tailrace (the downstream part of a dam where the impounded water re-enters the river) of the turbines. The tailrace station (noted Tail., $5^{\circ} 03.89^{\prime} \mathrm{N}-53^{\circ} 02.85^{\prime} \mathrm{W}$ ) reflected the average conditions of the hypolimnetic dam discharges (approximately $180 \mathrm{~m}^{3} \mathrm{~s}^{-1}$ ). The oxygenated freshwaters tributaries of the USE were sampled during Matoutou 2, 3, 4 and 5 sampling campaigns (Tab. 1). Four main tributaries were investigated, namely the Gregoire, Chapeau, Venus and Saulnier creeks. These accounted for about one fifth of the total freshwater flow to the USE (approximately $50 \mathrm{~m}^{3} \mathrm{~s}^{-1}$ ).

\subsection{Sample collection}

Subsurface water samples were collected $20 \mathrm{~cm}$ below the air-water interface (AWI) by immersing an acid washed Teflon bottle (FEP) with a gloved hand. Analyses of dissolved gaseous mercury (DGM) were performed within 2 hours of collection at the dam field laboratory (HYDRECO). The sum of all $\mathrm{Hg}$ species (unfiltered $\mathrm{HgT}$ or $\mathrm{HgT}_{\mathrm{UNF}}$ ) along with the dissolved $\left(\mathrm{Hg}_{\mathrm{D}}\right)$ and reactive ( $\left.\mathrm{HgR}_{\mathrm{UNF}}\right)$ fractions were processed the same day. Aliquots were kept to determine MMHg in the unfiltered (MMHgunF), dissolved $\left(\mathrm{MMHg}_{\mathrm{D}}\right)$ and the particulate $\left(\mathrm{MMHg}_{\mathrm{P}}\right)$ phases. Water samples were filtered using hydrophilic Teflon membranes $\left(0.45 \mu \mathrm{m}\right.$ pore size, $45 \mathrm{~mm}$ diameter, $\mathrm{LCR}^{\circledR}$, Millipore) and acidified with $0.5 \%(\mathrm{v} / \mathrm{v}) \mathrm{HCl}$ (Suprapur ${ }^{\circledR}$, Merck). The filtrates were operationally defined as "dissolved" but there is no claim being made that filtration through $0.45 \mu \mathrm{m}$ is a true separation of suspended and dissolved forms of $\mathrm{Hg}$. Used filters (particulate samples) and corresponding filtered solutions were ultimately double bagged and stored at $-20^{\circ} \mathrm{C}$ in dark conditions until analysis. 


\subsection{Sample analysis}

\subsubsection{Ancillary parameters}

The $\mathrm{pH}$, dissolved oxygen, conductivity and redox were recorded in situ with a YSI 600XLM multiparameter probe. Total sulfides $\left(\mathrm{LH}_{2} \mathrm{~S}\right)$ "dissolved" $(<0.45 \mu \mathrm{m})$ sulfate $\left(\mathrm{SO}_{4}\right)$ and dissolved iron ( $\mathrm{FeT}_{\mathrm{D}}$ including both $\mathrm{Fe}^{\mathrm{II}}$ and $\mathrm{Fe}^{\mathrm{III}}$ measurements) were measured by colorimetry (Merck, 2001). Samples for organic carbon in the unfiltered (TOC) and the dissolved (DOC) phases were analyzed by IR spectroscopy after oxidative or acidic digestion of the samples.

\subsubsection{Mercurial speciation in water and particles}

All Hg species were quantified using cold vapor atomic fluorescence spectrometry (CVAFS). HgT was determined according to Bloom and Fitzgerald (1988), by the formation of volatile elemental $\mathrm{Hg}$ (released by $\mathrm{SnCl}_{2}$ reduction, after 30 minutes of acidic $\mathrm{BrCl}$ oxidation) and preconcentration on a gold trap. $\mathrm{HgR}$ (the easily reducible fraction) was obtained by direct reduction with $\mathrm{SnCl}_{2}(\mathrm{pH} 1)$. Unfiltered samples were analyzed for dissolved gaseous mercury (DGM mainly $\mathrm{Hg}^{0}$ ) by sparging for 20 min with $\mathrm{Hg}$-free argon at $200 \mathrm{~mL} \mathrm{~min}^{-1}$. The detection limits, defined as 3.3 times the standard deviation of the blanks, were usually $0.05 \mathrm{pmol} \mathrm{L}^{-1}$ for $\mathrm{HgT}$ and $\mathrm{HgR}$, and $25 \mathrm{fmol} \mathrm{L}^{-1}$ for DGM. The sample volume analyzed for $\mathrm{HgT}, \mathrm{HgR}$ and DGM was between 50 and $100 \mathrm{~mL}$. The relative standard deviation, calculated on five replicate samples of about $0.5 \mathrm{pmol} \mathrm{L}^{-1}$, was lower than $10 \%$. The mean recovery and variance associated with the accuracy for $\mathrm{HgT}$ determinations were $93 \pm 5 \%$ and were regularly checked, using the reference material (ORMS-3) from the National Council of Canada as certified reference material (CRM). MMHg was determined in the unfiltered (MMHgunF) and dissolved $\left(\mathrm{MMHg}_{\mathrm{D}}\right)$ phases using the method proposed by Bloom (1989) and modified by Liang et al. (1994) and Leermakers et al. (2001). The water samples were stored with $0.5 \%(\mathrm{v} / \mathrm{v}) \mathrm{HCl}$, which is a reliable method for a 3 week storage period (Parker and Bloom, 2005). MMHg in acidified water was extracted by $\mathrm{CH}_{2} \mathrm{Cl}_{2}$ and then transferred into $40 \mathrm{~mL}$ of Milli-Q water by evaporating the organic solvent. The aqueous solutions were analyzed for $\mathrm{MMHg}$ by gas chromatography after ethylation and adsorption / desorption on a Tenax ${ }^{\circledR}$ column. For $\mathrm{HgT}_{\mathrm{P}}$ and $\mathrm{MMHg}_{\mathrm{P}}$ in suspended particulate matters (SPM), an acidic dissolution (with concentrated $\mathrm{HCl} / \mathrm{HNO}_{3}$ ) of the filtered particles took place before the procedures described previously. Detection limits for $\mathrm{MMHg}$ were $0.01 \mathrm{pmol} \mathrm{L}^{-1}$ and $0.005 \mathrm{pmol} \mathrm{g}^{-1}$ for respectively a $100 \mathrm{~mL}$ water and $200 \mathrm{mg}$ solid sample. Precision was bellow $10 \%$ for all analyses. Using the available reference material (IAEA-405), the accuracy of the method was estimated to be 91 $\pm 8 \%$ recovery. The detailed procedure is given by Cossa et al. (2002 and 2003).

\subsection{Modeling the mercurial scavenging and complexation}

\subsubsection{Modeling the mercurial scavenging}

The scavenging of dissolved $\mathrm{Hg}\left(\mathrm{Q}_{\mathrm{a}}, \mathrm{kg}\right)$ was formulated as the product of the average trapping coefficient of $\mathrm{Hg}\left(\mathrm{k}\right.$, no units) and the local consumption of scavenging agent $\left(\mathrm{Q}_{\mathrm{s}}, \mathrm{kg}\right)$ :

$$
\mathrm{Q}_{\mathrm{a}}=\mathrm{k} \mathrm{Q}_{\mathrm{s}}
$$

The equilibrium between dissolved $\mathrm{Hg}$, ligands and suspended matters is usually based on the surface complexation theory (Stumm et al., 1980; Westall, 1987; Dzombak and Morel, 1990). In this approach, the high affinity of $\mathrm{Hg}$ for sulfides, oxyhydroxides, and OM ensures that equilibrium between the dissolved and the solid phases is quickly achieved (Morel et al., 1998). Hence, dissolved Hg levels are essentially driven by the available quantity of sorbent:

$$
\begin{aligned}
& \Delta[\mathrm{A}]=-\mathrm{k} \Delta[\mathrm{S}] ; \mathrm{k}=\frac{[\mathrm{SA}]}{\mathrm{K}_{\mathrm{ads}}[\mathrm{S}]^{2}} \\
& \mathrm{~S}+\mathrm{A} \Leftrightarrow \mathrm{SA} ; \quad \mathrm{K}_{\mathrm{ads}}=\frac{[\mathrm{SA}]}{[\mathrm{S}][\mathrm{A}]}
\end{aligned}
$$




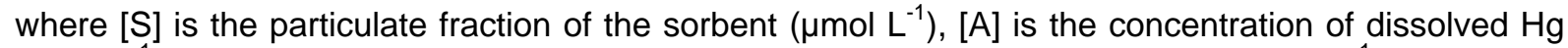
$\left(\mathrm{pmol} \mathrm{L^{-1 }}\right.$ ) and $[\mathrm{SA}]$ is the concentration of the Hg-sorbent bounded complexes (pmol $\mathrm{L}^{-1}$ ). Calling [D] the dissolved fractions of the sorbent $\left(\mu \mathrm{mol} \mathrm{L}^{-1}\right)$ and considering that the total amount of sorbent in the USE remains relatively unchanged (this was testified for total S, FeT and TOC):

$$
\mathrm{k}=-\frac{\Delta[\mathrm{A}]}{\Delta[\mathrm{S}]} \approx \frac{\Delta[\mathrm{A}]}{\Delta[\mathrm{D}]}
$$

One could thus approach the trapping coefficient $(\mathrm{k})$ by measuring the concentrations of dissolved $\mathrm{Hg}$ along with that of dissolved scavenging agent (i.e. $\Sigma \mathrm{H}_{2} \mathrm{~S}, \mathrm{FeT}_{\mathrm{D}}$ and DOC).

\subsubsection{Modeling the mercury complexation}

The speciation code line Winderemere Humic Aqueous Model (WHAM 6; Tipping, 2002) was used to probe the speciation of dissolved and particulate strongly complexed $\mathrm{Hg}\left(\mathrm{Hg}_{\mathrm{sc}}=\mathrm{HgT}-\mathrm{HgR}-\mathrm{MMHg}\right.$; Mason et al., 1993), and dissolved MMHg in the USE. In the WHAM 6 approach, humic compounds are represented by hypothetical size-homogenous, rigid, molecules, which carry proton-dissociating groups that can bind metal ions either singly or as bidentate pairs. Inputs to the WHAM 6 speciation code line were in compliance with Goulet et al. (2007). Briefly, inputs consisted of the $\mathrm{pH}$, [HgTsc], [MMHg $],\left[\Sigma \mathrm{H}_{2} \mathrm{~S}\right],[\mathrm{Al}],[\mathrm{Fe}],[\mathrm{Mn}]$ and major ions, as well as estimates of humic (HA) and fulvic (FA) acid concentrations. To estimate $[\mathrm{HA}]$ and $[\mathrm{FA}]$, we assumed that DOC contained $50 \% \mathrm{C}$ (Buffle, 1988) and that all DOC was humic substances with a ratio of [FA]:[HA] of 9:1 (Malcolm, 1985). The WHAM 6 thermodynamic databases was updated with the equilibrium constants for the systems $\mathrm{Hg}$ sulfide-polysulfide and MeHg-sulfide given in Goulet et al. (2007), and dissolved elemental sulfur $\left(\mathrm{S}_{(\mathrm{aq})}{ }\right)$ and $\mathrm{MeHg}^{+}$were added as components in the code. The formation constants recommended by the National Institute of Standards and Technology (NIST, 2004) and Powell et al. (2005) for Hg complexation with $\mathrm{OH}^{-}, \mathrm{Cl}^{-}, \mathrm{NO}_{3}{ }^{-}$and $\mathrm{CO}_{3}{ }^{2-}$ were also used to update the WHAM 6 databases. The intrinsic equilibrium constant for $\mathrm{Hg} \mathrm{MMHg}$ complexes with $\mathrm{FA}$ and $\mathrm{HA}$ used in the calculations were those estimated by Tipping (2007).

\section{Results and Discussion}

\subsection{Chemical characteristics of the waters}

Figure 2 displays the transects for $\mathrm{pH}$, redox (Eh), conductivity, particulate organic carbon (POC), dissolved organic carbon (DOC), oxygen $\left(\mathrm{O}_{2}\right)$, iron $\left(\mathrm{FeT}_{\mathrm{D}}\right)$ and sulfides $\left(\mathrm{SH}_{2} \mathrm{~S}\right)$ obtained during the Matoutou 1, 2, 3, 4 and 5 campaigns at the nine (Tail., Pas., Ker., Cha., Ven., Bra., Com., Deg. and Sin.) stations. The $\mathrm{pH}$ in the USE was plainly acidic $(5.7 \pm 0.3$; average \pm SD). The longitudinal distribution of Eh increased with distance from the dam (from 150 to $400 \mathrm{mV}$ ) while $\mathrm{O}_{2}$ and conductivity showed patterns of gradual decrease and low levels (approximately $0.1 \mathrm{mmol} \mathrm{L}^{-1}$ and $<30$ $\mu \mathrm{S} \mathrm{cm}{ }^{-1}$, respectively) were reached between Com. and Sin. stations. Since Eh is a proxy of the concentration of reducing agents, we observed a gradual oxidation of the water masses along their course to the Atlantic Ocean.

De Junet (2004) stated that carbon exportations downstream of the dam in 2003, circa $8010^{9} \mathrm{~g} \mathrm{C} \mathrm{y}^{-1}$, were dominated by volatile compounds $\left(5010^{9} \mathrm{~g} \mathrm{C} \mathrm{y}^{-1}\right.$ mostly as $\mathrm{CO}_{2}$ and $\mathrm{CH}_{4}$ ). During the Matoutou sampling campaigns, TOC in the USE averaged $0.47 \pm 0.02 \mathrm{mmol} \mathrm{L}^{-1}$ of which $90 \%(0.41 \pm 0.04$ $\mathrm{mmol}^{-1}$ ) was DOC (Fig. 2). With distance from the dam, we observed a gradual increase of POC (from < d.l. to $0.08 \mathrm{mmol} \mathrm{L}^{-1}$ ) to the detriment of DOC (from 0.48 to $0.37 \mathrm{mmol} \mathrm{L}^{-1}$ ). Hence, an inverse behavior was reported with the $\mathrm{O}_{2}$ up to saturation (\%) $\left\{\mathrm{r}^{2}=0.45 ; \mathrm{O}_{2}(\%)=-600[\mathrm{POC}]_{\mathrm{mmol} L-1}+93\right\}$. The maximum of $\mathrm{OM}$ mineralization (minimum of $\mathrm{POC}$ ) was located within the first kilometers downstream of the Petit-Saut dam and developed during the wet seasons. Quantitatively, the 
mineralization of autochthonous particulate OM in the USE represented $30 \%$ of its gaseous $\mathrm{CO}_{2}$ and $\mathrm{CH}_{4}$ emissions (De Junet, 2004).

In the USE, FeT $T_{D}$ averaged $8 \pm 6 \mu \mathrm{mol} \mathrm{L^{-1 }}$. The highest concentrations $\left(17 \pm 6 \mu \mathrm{mol} \mathrm{L}^{-1}\right)$ were measured at the tailrace (Fig. 2) and corresponded to up to 7000 tons $\mathrm{y}^{-1}$ of $\mathrm{FeT}_{\mathrm{D}}$ discharged downstream of the dam. The FeT $T_{D}$ negatively correlated with redox $\left(\mathrm{r}^{2}=0.62 ;\left[\mathrm{FeT}_{\mathrm{D}}\right]_{\mu \mathrm{mol}} \mathrm{L}-1=-0.08\right.$ $E h_{m v}+30$ ). Simultaneous removal of both iron and oxygen from the dissolved phase suggested a partial oxidation of $\mathrm{FeT}_{\mathrm{D}}$ (presumably $\mathrm{Fe}^{2+}$ ) to $\mathrm{Fe}$ oxyhydroxides. Maximum of $\mathrm{Fe}^{\mathrm{III}}$ concentrations (around $50 \mu \mathrm{mol} \mathrm{L}^{-1}$ ) were located in the vicinity of the Ker. station circa $20 \mathrm{~km}$ downstream of the dam (15 $\pm 8 \mu \mathrm{mol} \mathrm{L}^{-1}$ of $\mathrm{Fe}$ ). The $\Sigma \mathrm{H}_{2} \mathrm{~S}$ concentrations in the USE ranged from $<0.1$ to $2 \mu \mathrm{mol} \mathrm{L}^{-1}$ (Fig. 2) and averaged $0.7 \pm 0.5 \mu \mathrm{mol} \mathrm{L}^{-1}$. The $\Sigma \mathrm{H}_{2} \mathrm{~S}$ concentrations markedly decreased in the first kilometers downstream of the dam. Formation of sulfates through in situ $\Sigma \mathrm{H}_{2} \mathrm{~S}$ oxidation coupled with locally reducing $(<200 \mathrm{mV})$ and suboxic $\left(<0.1 \mathrm{mmol} \mathrm{L}^{-1} \mathrm{O}_{2}\right)$ conditions would contribute to sustain the USE endogenous activity of SRB. This was confirmed by water and biofilms incubation experiments that developed substantial SRB concentrations (Jorand pers. com.).

\subsection{Mercury inputs to the Estuary}

\subsubsection{The role of the dam}

$\mathrm{HgT}_{\text {UNF }}$ concentrations at the Tail. station varied between $3.8 \mathrm{pmol} \mathrm{L}^{-1}$ (June 2003) and $27.9 \mathrm{pmol} \mathrm{L}^{-1}$ (July 2004; Fig. 3). Average HgT UNF concentration was $13 \pm 5 \mathrm{pmol} \mathrm{L}^{-1}$ of which about $60 \%(8 \pm 2$ pmol L ${ }^{-1}$ ) were $\mathrm{HgT}_{\mathrm{D}}$ (Tab. 2). We observed (Fig. 3) a trend towards high HgT UNF concentrations (up to $28 \mathrm{pmol} \mathrm{L}^{-1}$ ) in the beginning and the middle of dry seasons (March to April then August to November). The wet seasons (May to July then December to February) displayed the lowest values (down to 4 pmol L ${ }^{-1}$ ). This pattern was in agreement with the fact that reduced species were concentrated in the hypolimnion of the reservoir during the dry season and were diluted in the course of the wet season (Muresan et al., 2008; Tab. 3). The mean flow of water leaving the reservoir averaged $180 \pm 70 \mathrm{~m}^{3} \mathrm{~s}^{-1}$ for the 2003/04 period. From the tailrace monitoring data, average MMHgunF and DGM concentrations in discharged waters were estimated to $2.5 \pm 1.5$ and $0.4 \pm 0.2 \mathrm{pmol} \mathrm{L}^{-1}$, respectively. Hence, the exportations of $\mathrm{HgT}_{\mathrm{UNF}}, \mathrm{HgT}_{\mathrm{D}}, \mathrm{MMHg}_{\mathrm{UNF}}$ and $\mathrm{DGM}$ were calculated to be $16 \pm 5,9 \pm 2,3 \pm 1$ and $0.4 \pm$ $0.2 \mathrm{~kg} \cdot \mathrm{y}^{-1}$ respectively.

\subsubsection{The role of tributaries}

Local tributaries to the USE displayed HgT UNF concentrations varying from 5.0 to $19.5 \mathrm{pmol} \mathrm{L}^{-1}$ and averaging $13 \pm 5 \mathrm{pmol} \mathrm{L}^{-1}$ (Tab. 2). Except for the high runoff episodes, $\mathrm{HgT}_{\mathrm{D}}$ appeared to dominate the HgTunf partitioning $\left(7 \pm 2\right.$ pmol L $\mathrm{L}^{-1}, \mathrm{Tab}$. 3). Maxima of $\mathrm{HgT}_{\mathrm{UNF}}$ were measured during the wet seasons (January-February and May-June 2004). At that time, $80 \%$ of the $\mathrm{HgT}_{\mathrm{UNF}}\left(17 \pm 4 \mathrm{pmol} \mathrm{L}^{-1}\right)$ consisted of $\mathrm{HgT}_{\mathrm{P}}\left(14 \pm 5 \mathrm{pmol} \mathrm{L}^{-1}\right.$ i.e., $\left.800 \pm 600 \mathrm{pmol} \mathrm{g}^{-1}\right)$. Despite the HgT partitions $(5.0 \pm 0.4 \mathrm{vs}$. $4.8 \pm 0.4$ of $\log _{\mathrm{HgT}}$ respectively) and concentrations in the tributaries and the dam tailrace waters were similar, we measured marked differences in the $\mathrm{Hg}$ speciation. The water samples from the tributaries displayed higher concentrations of $\operatorname{HgR}_{\mathrm{UNF}}\left(1.3 \pm 0.7 \mathrm{vs} .0 .5 \pm 0.1 \mathrm{pmol} \mathrm{L}^{-1}\right.$, respectively) but lower concentrations of DGM (0.11 \pm 0.09 vs. $0.4 \pm 0.2 \mathrm{pmol} \mathrm{L}^{-1}$, respectively) and $\mathrm{MMHg}$ in the dissolved ( $0.8 \pm 0.5$ vs. $1.6 \pm 0.7$ pmol L $^{-1}$, respectively) and the particulate ( $80 \pm 60$ vs. $150 \pm 100$ pmol g ${ }^{-1}$, respectively) phases. The amounts of $\mathrm{Hg}$ transported by tributaries to the USE were $4 \pm 3,2$ $\pm 1,0.5 \pm 0.2$ and $0.03 \pm 0.02 \mathrm{~kg} \cdot \mathrm{y}^{-1}$ for $\mathrm{HgT}_{\mathrm{UNF}}, \mathrm{HgT}_{\mathrm{D}}, \mathrm{MMHg}_{\mathrm{UNF}}$ and DGM, respectively. These represented $25,20,15$ and $8 \%$ of the dam exportations.

\subsection{Water oxygenation and $\mathrm{Hg}$ speciation}

\subsubsection{The artificial oxygenation system}

The role of the artificial oxygenation of waters (100 m downstream of the dam, Fig. 1) was evaluated by determining $\mathrm{Hg}$ speciation on both sides of the aeration system. While $\mathrm{HgT}_{\mathrm{UNF}}$ and $\mathrm{HgT}_{\mathrm{D}}$ were similar (Fig. 4; Tail. vs. Pas. stations), DGM concentrations dropped by $40 \%$. The total atmospheric gaseous $\mathrm{Hg}$ within $10 \mathrm{~m}$ above the aeration system peaked from the "background" levels $(10 \mathrm{pmol} \mathrm{m}$ 
${ }^{3}$ ) to up to $60 \mathrm{pmol} \mathrm{m}^{-3}$ (Muresan et al., 2007). These measurements suggest a notable "evasion" of volatile $\mathrm{Hg}$. There was a statistically significant increase (approximately $50 \%$ ) in $\mathrm{MMHg}_{\mathrm{D}}$ between Tail. and Pas. sampling stations during each survey (Tab. 3). Two paired processes might account for this observation: (i) an intense biological reduction of sulfates initiated by the sudden oxygenation of the waters expelled from the dam, and (ii) an oxidative dissolution of MMHg loaded AVS (acid volatile sulfides). Considering the first mechanism, large amounts of organic substrata $\left(0.44 \pm 0.07 \mathrm{mmol} \mathrm{L}^{-1}\right.$ of TOC) combined with high $\mathrm{Hg}$ concentrations (13 $\pm 5 \mathrm{pmol} \mathrm{L}^{-1}$ of HgT UNF) and sulfidic conditions (1.2 $\pm 0.8 \mu \mathrm{mol} \mathrm{L} \mathrm{L}^{-1}$ of $\Sigma \mathrm{H}_{2} \mathrm{~S}$ ) depicted the tailrace as a likely zone for $\mathrm{Hg}$ methylation. According to Dumestre et al. (2001), $\Sigma \mathrm{H}_{2} \mathrm{~S}$-producing and $\Sigma \mathrm{H}_{2} \mathrm{~S}$-consuming bacteria are closely associated within the dam expelled waters. Cycling such as this represented a small but extremely active proportion of the microbial assemblage. Considering the second mechanism, dam expelled waters mainly originated from AVS and $\mathrm{MMHg}_{\mathrm{p}}$ enriched layer of the hypolimnion (between 8 and $15 \mathrm{~m}$ ). Partial dissolution of the discharged particles would therefore provide high $\mathrm{MMHg}_{\mathrm{D}}$ levels into the Sinnamary Estuary. Accordingly, the MMHg log partition coefficient $\left[\log K_{\mathrm{d}}(\mathrm{MMHg}) ; K_{\mathrm{d}}(\mathrm{MMHg})=\mathrm{MMHg} / \mathrm{MMHg}_{\mathrm{p}}\right]$ decreased from $5.4 \pm 0.2$ to $4.7 \pm 0.3$ in less than $300 \mathrm{~m}$.

\subsubsection{Mixing with the oxygenated waters from the creeks}

Reaching the USE, the $\mathrm{Hg}$ from the tributaries underwent rapid speciation changes through complexation and methylation mechanisms. The primary variable related to $\mathrm{Hg}$ speciation changes was $\Sigma \mathrm{H}_{2} \mathrm{~S}$. In the tributaries, the higher concentrations of dissolved $\mathrm{O}_{2}\left(0.16 \pm 0.05 \mathrm{mmol} \mathrm{L}^{-1}\right)$ contributed to maintain the $\Sigma \mathrm{H}_{2} \mathrm{~S}$ levels low $\left(0.5 \pm 0.4 \mu \mathrm{mol} \mathrm{L} \mathrm{L}^{-1}\right)$. Accordingly, the pool of reduced ligands available for $\mathrm{Hg}$ complexation [as strong $\mathrm{Hg}$-S compounds; e.g. $\log K=36.9$ for $\mathrm{Hg}^{2+}+2 \mathrm{HS}^{-}=$ $\mathrm{Hg}(\mathrm{HS})_{2}$ ] was less important in the tributaries than in the tailrace waters. It is generally accepted that strong complexing agents act to lower the reduction potential of metals (van den Berg, 1984). This was supported by increased $\mathrm{HgR}_{\mathrm{UNF}}$ concentrations in the tributaries $\left(1.3 \pm 0.7 \mathrm{pmol} \mathrm{L}^{-1}\right.$; the inherent reduction cutoff of $\mathrm{SnCl}_{2}$ is about $\left.\mathrm{LogK}_{\mathrm{HgR}}=19\right)$. In the USE, $\mathrm{HgR}_{\mathrm{UNF}}$ and $\mathrm{MMHg}_{\mathrm{D}}$ concentrations were higher near creeks Kerenrock, Chapeau and Venus. Therefore, $\mathrm{HgR}_{\mathrm{UNF}} / \mathrm{HgT}_{\mathrm{UNF}}$ (\%) positively correlated with $\mathrm{MMHg}_{\mathrm{D}} / \mathrm{HgT}_{\mathrm{D}}(\%)\left\{\mathrm{r}^{2}=0.51 ;\left[\mathrm{MMHg}_{\mathrm{D}} / \mathrm{HgT}_{\mathrm{D}}(\%)\right]=6.4\left[\mathrm{HgR}_{\mathrm{UNF}} / \mathrm{HgT}_{\mathrm{UNF}}(\%)\right]+0.43\right\}$ (data not shown). This indicated that the more labile $\mathrm{HgR}_{\mathrm{UNF}}$ specie from the tributaries may constitute an important source for $\mathrm{Hg}$ complexation with $\Sigma \mathrm{H}_{2} \mathrm{~S}$ and subsequent $\mathrm{MMHg}$ production in the USE.

\subsection{Total mercury transport and distribution}

$\mathrm{HgT}_{\mathrm{UNF}}$ and $\mathrm{HgT}_{\mathrm{D}}$ in the USE averaged (range) $11 \pm 3(5.9-16.9)$ and $6 \pm 2(2.2-10.5) \mathrm{pmol} \mathrm{L}^{-1}$, respectively (Fig. 4). Between Tail. (dam end-member) and $\mathrm{Sin}$. (saline end-member) stations, $\mathrm{HgT}_{\mathrm{D}}$ decreased from $9 \pm 2$ to $5 \pm 2$ pmol L $^{-1}$ (i.e. from 80 to $60 \%$ of HgT UNF). USE HgT $T_{D}$ concentrations were highest in long dry season $\left(9 \pm 1 \mathrm{pmol} \mathrm{L}^{-1}\right)$ declined in the short wet and dry (orderly $5 \pm 2$ and 7 $\left.\pm 1 \mathrm{pmol} \mathrm{L}^{-1}\right)$ seasons and reached a minimum in long wet season $\left(3 \pm 1 \mathrm{pmol} \mathrm{L}{ }^{-1}\right)$. USE $\mathrm{HgT}_{\mathrm{D}}$ concentrations measured in the dry seasons $\left(8 \pm 1 \mathrm{pmol} \mathrm{L}^{-1}\right)$ reflected the average hypolimnion of the reservoir ( $8 \pm 2 \mathrm{pmol} \mathrm{L}^{-1}$; Tab. 2, Section 4.2.1.). The decrease in $\mathrm{HgT}_{\mathrm{D}}$ during the wet season $(4 \pm 2$ pmol $\left.\mathrm{L}^{-1}\right)$ likely resulted from the dilution of the dam outflow by downstream tributaries $\left(5 \pm 2 \mathrm{pmol} \mathrm{L}^{-1}\right)$ or lateral runoff waters.

High percentages of dissolved strongly complexed mercury (50 $\pm 10 \%$ of the $\mathrm{HgT}_{\mathrm{D}}$; calculated as $\mathrm{Hg}_{\mathrm{DSC}}=\mathrm{Hg}_{\mathrm{D}}-\mathrm{HgR}_{\mathrm{D}}-\mathrm{MMHg}_{\mathrm{D}}$ ) revealed that a notable proportion of $\mathrm{HgT}_{\mathrm{D}}$ in the USE was bound to dissolved OM (DOM) and sulfides (as these strong ligands controls the $\mathrm{Hg}$ speciation in solution in low oxygen zones). Colloids depict a transitional domain (from $10^{-3}$ to $1 \mu \mathrm{m}$ ) between which was considered dissolved $(<0.45 \mu \mathrm{m})$ and particulate $(>0.45 \mu \mathrm{m})$ material. In the USE, intense degradation of OM suggested that organic ligands (such as thiols) played a major role in the complexation of $\mathrm{HgT}_{\mathrm{D}}$ (Fig. 5). Using our data, we determined the speciation of $\mathrm{Hg}_{\mathrm{Dsc}}$ in the presence of DOM and $\Sigma \mathrm{H}_{2} \mathrm{~S}$ by running the speciation code line WHAM 6 . The calculations showed that the proportions of Hg bound to DOM were between 35 and $45 \%$ (42 $\pm 4 \%$ on average) and increased with the distance from the dam. These calculations were supported by a positive correlation between $\mathrm{HgT}_{\mathrm{D}}$ and $\mathrm{DOC}\left(\mathrm{r}^{2}\right.$ $=0.78$ ). The presence of micromolar $\Sigma \mathrm{H}_{2} \mathrm{~S}$ pointed out an extra contribution of sulfidic ligands. Rozan et al. (2000) stated that metal-sulfide complexes (Fe-S, Zn-S and Cu-S) can persist for weeks under oxic conditions. Besides, Hsu-Kim and Sedlak (2005) observed strong Hg-S complexes in the sulfidic 
effluents from municipal wastewater. Using mole ratios similar to those observed for $\mathrm{Cu}$ and $\mathrm{Zn}$ [predominantly 1:1 metal to sulfur ratio $\left(\mathrm{M}_{3} \mathrm{~S}_{3}\right)$ and a small quantity of compounds with a 2:3 metal to sulfur ratio $\left(\mathrm{M}_{4} \mathrm{~S}_{6}\right)$ ], strong $\mathrm{Hg}$-S complexes were calculated to have thermodynamic stability constants up to $\log \beta=130.4\left(\mathrm{Hg}_{3} \mathrm{~S}_{3}\right)$ and $\log \beta=194.7\left(\mathrm{Hg}_{4} \mathrm{~S}_{6}\right)$. In the USE, strong $\mathrm{Hg}$-S complexes constituted more than $50 \%$ of the Hgsc but their contribution decreased with the distance from the dam (from 65 down to $53 \%$ ). From the observed decrease, the average half-life of the strong $\mathrm{Hg}-\mathrm{S}$ pool of complexes was estimated to be 3-7 days.

Since DOM and inorganic sulfides competed for $\mathrm{Hg}$ binding, we observed a "U" shape relationship between $\mathrm{HgT}_{\mathrm{D}}$ and. $\Sigma \mathrm{H}_{2} \mathrm{~S}$ (Fig. 5). High $\Sigma \mathrm{H}_{2} \mathrm{~S}$ concentrations $\left(>1 \mu \mathrm{mol} \mathrm{L}^{-1}\right)$ would enhance the $\mathrm{Hg}$ mobilization through thermodynamic equilibrium with cinnabar $\left(\mathrm{HgS}_{(\mathrm{s})}\right)$ : formation of $\mathrm{Hg}$-S complexes

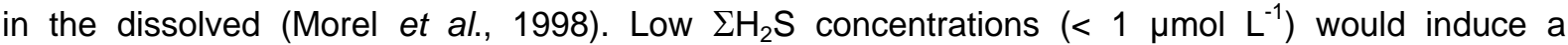
predominance of the oxidative dissolution processes (e.g. of AVS and $\mathrm{Hg}-\mathrm{S}$ clusters) and thus enhance the $\mathrm{Hg}$ transfer to the DOM. Hence, around $1 \mu \mathrm{mol} \mathrm{L} \mathrm{L}^{-1}$ of $\Sigma \mathrm{H}_{2} \mathrm{~S}$, limited formation of $\mathrm{Hg}-\mathrm{S}$ complexes and $\mathrm{Hg}$ transfer to the DOM would correspond to a maximum for $\mathrm{HgT}_{\mathrm{D}}$ scavenging.

Average concentrations of $\mathrm{HgT}_{\mathrm{D}}$ in the USE were $30 \%$ lower than the average concentrations at the Tail. station (Tab. 2). The positive correlation between $\mathrm{FeT}_{\mathrm{D}}$ and $\Sigma \mathrm{H}_{2} \mathrm{~S}\left(\mathrm{r}^{2}=0.82\right)$ suggested a dynamic equilibrium between dissolved species and iron sulfides (monosulfide/AVS and/or pyrite). Their elevated specific surface (several $\mathrm{m}^{2} \mathrm{~g}^{-1}$ ) coupled with the high affinity of $\mathrm{Hg}$ for sulfide ligands depicted AVS as potential scavenging agents. Beyond AVS, the main pathway for $\mathrm{Hg}_{\mathrm{D}}$ scavenging was related to Fe oxyhydroxides. The most abundant metal in solution, $\mathrm{FeT}_{\mathrm{D}}$ decreased from $18 \pm 5$ to $4 \pm 2 \mu \mathrm{mol} \mathrm{L}{ }^{-1}$ between Tail. and Sin. stations. $30 \pm 10 \%$ of the observed decrease originated from the artificial aeration of waters circa $100 \mathrm{~m}$ downstream of the dam (Fig.2). Thus, applying the model described in Section 2.3. to the $\mathrm{HgT}_{\mathrm{D}}$ vs. $\mathrm{FeT}_{\mathrm{D}}$ relationship $\left(\mathrm{r}^{2}=0.69\right)$, we estimated that $400 \pm 100$ nmol of $\mathrm{HgT}_{\mathrm{D}}$ are scavenged per mol of oxidized $\mathrm{FeT}_{\mathrm{D}}$ (Fig. 5). As circa 7000 tons of $\mathrm{FeT}_{\mathrm{D}}$ were exported from the dam annually, oxidation of $\mathrm{Fe}$ "l to Fe oxyhydroxides would have removed $10 \pm 3 \mathrm{~kg}$ $\mathrm{y}^{-1}$ of $\mathrm{Hg}$ from the dissolved phase. This high-end estimate is lower than annual dam exportations of $\mathrm{HgT}_{\mathrm{UNF}}\left(16 \mathrm{~kg} \mathrm{y}^{-1}\right)$ but exceeded those of $\mathrm{HgT}_{\mathrm{D}}\left(9 \mathrm{~kg} \mathrm{y}^{-1}\right)$.

\subsection{Gaseous mercury production and consumption}

Between the Petit-Saut dam and Sin. station (70 km downstream), DGM decreased from $0.37 \pm 0.10$ to $0.14 \pm 0.10 \mathrm{pmol} \mathrm{L}^{-1}$. This corresponded to an average diminution greater than $60 \%$ (Fig. 4). The amount of DGM transferred to the atmosphere was calculated by multiplying the annual amount of discharged water (about $610^{9} \mathrm{~m}^{3}$ ) and the overall average decrease of DGM concentrations for all surveys $\left(0.23 \pm 0.10 \mathrm{pmol} \mathrm{L}^{-1}\right)$. This calculation supposed that the measured DGM decrease issued only from degassing processes and that endogenous DGM production was negligible. Thus, the USE transferred $0.2 \pm 0.1 \mathrm{~kg} \mathrm{y}^{-1}$ of $\mathrm{Hg}^{0}$ to the atmosphere which represented less than $2 \%$ of the dam exported amount of $\mathrm{HgT}_{\text {UNF }}\left(16 \mathrm{~kg} \mathrm{y}^{-1}\right)$. About $50 \%$ (i.e. $0.1 \mathrm{~kg} \mathrm{y}^{-1}$ ) of the transferable DGM degassed when passing through the artificial aeration system.

The reduced penetrability of light $(<1 \mathrm{~m})$ limited the $\mathrm{Hg}$ photoreduction. We thus probed the abiotic $\mathrm{Hg}^{0}$ production by the $\mathrm{Fe}$ " to $\mathrm{Fe}(\mathrm{OH})_{3}$ oxidation in the presence of hematite particles: adsorption of $\mathrm{Fe}^{\prime \prime}$ to the surface of haematite nanoparticles creates very reactive sites for the $\mathrm{Hg}^{\prime \prime}$ reduction (Peretyazhko et al. 2006). Gained data showed that a maximum of DGM production (2 pmol $\left.\mathrm{L}^{-1} \mathrm{~h}^{-1}\right)$ was concomitant to a Fe" decrease in the dissolved phase (from 20 to $8 \mu \mathrm{mol} \mathrm{L}^{-1}$ ). In the USE, between Tail. and Ven. stations, the suspended particles of hematite were visible by sight. In addition, the DGM production by $\mathrm{Fe}^{\prime \prime}$ to $\mathrm{Fe}(\mathrm{OH})_{3}$ oxidation was apparent by a positive correlation between DGM and $\mathrm{FeT}_{\mathrm{D}}$ concentrations $\left(\mathrm{r}^{2}=0.73\right)$ (Figs. 2 and 4). We calculated that $15 \pm 3 \mathrm{nmol}$ of DGM are in equilibrium with every mol of $\mathrm{FeT}_{\mathrm{D}}$ (Fig. 5). As roughly 7000 tons of $\mathrm{FeT}_{\mathrm{D}}$ were annually discharged downstream of the dam, $0.3 \pm 0.1 \mathrm{~kg} \mathrm{y}^{-1}$ of DGM would have been abiotically produced. As a result, $\mathrm{Fe}$ driven production of DGM within the first $30 \mathrm{~km}$ of the USE was almost equivalent to dam exportations $\left(0.4 \pm 0.2 \mathrm{~kg} \cdot \mathrm{y}^{-1}\right.$, Section 4.2.1).

In the USE, DGM scavenging resulted from both direct $\mathrm{Hg}^{0}$ oxidation and its strong complexation with $\mathrm{POC}$ (decrease of the $\mathrm{Hg}$ availability towards reduction). A negative correlation between DGM and POC $\left(r^{2}=78\right)$ supported these mechanisms (Fig.5). The OM plays a key role in the photochemical reduction of ionic $\mathrm{Hg}^{\prime \prime}$ to $\mathrm{Hg}^{0}$ (Alberts et al., 1974; Allard and Arsenie, 1991; Nriagu, 1994) and its subsequent reoxidation (Amyot et al., 1997; Ravichadran, 2004; O'Driscoll et al., 2006). In the presence of $\mathrm{O}_{2}$, the OM catalyzed $\mathrm{Hg}^{0}$ reoxidation can be formulated as: 


$$
2 \mathrm{CH}_{2} \mathrm{O}+\mathrm{Hg}^{0}+2.5 \mathrm{O}_{2} \rightarrow \mathrm{Hg}(\mathrm{OH})_{2}+2 \mathrm{CO}_{2}+\mathrm{H}_{2} \mathrm{O}
$$

To probe this mechanism, we monitored the $\mathrm{HgR}_{\mathrm{D}}$ production that occurred during the DGM scavenging (as DGM oxidation should produce weak Hg complexes; data not shown). We determined that $30-50 \%$ of the scavenged DGM were oxidized as HgR. To probe the second mechanism, the complexation of DGM with POC was modeled by running the speciation code line WHAM 6. Between Tail. and Sin. sampling stations, the proportions of particulate strongly complexed $\mathrm{Hg}$ (calculated as $\mathrm{Hg}_{\mathrm{PSC}}=\mathrm{HgT}_{\mathrm{P}}-\mathrm{HgR}_{\mathrm{P}}-\mathrm{MMHg}_{\mathrm{P}}$ ) bound to POC increased from 22 to $27 \%$. Assuming that $10 \pm 7 \%$ (i.e. the average percentage of $\mathrm{DGM} / \mathrm{Hg}_{\mathrm{DSC}}$ ) of $\mathrm{Hg}$ PSC originated from DGM, we estimated that 10-30 $\%$ of the DGM scavenging results from strong complexation with POC. Overall, from the DGM vS. POC relationship, we calculated that $5 \pm 1 \mathrm{nmol}$ of DGM were scavenged per mol of POC in solution. Scaled to the $410^{9} \mathrm{~g} \mathrm{y}^{-1}$ POC discharged in the downstream of the dam, DGM scavenging in the USE compensated the Fe driven production of DGM (both $0.3 \pm 0.1 \mathrm{~kg} \mathrm{y}^{-1}$ ). Eventually, the atmospheric $\mathrm{Hg}$ evasion resulted from (i) the dam exportations, (ii) the net balance between in situ $\mathrm{Hg}$ reduction and oxidation processes, and (iii) the $\mathrm{Hg}^{0}$ complexation with POC.

In the USE, DGM negatively correlated with the log partition coefficient of $\mathrm{HgT}\left(\mathrm{r}^{2}=0.45\right)$ : DGM correlated positively with $\mathrm{HgT}_{D}\left(r^{2}=0.63\right)$ and negatively with $\mathrm{HgT}_{\mathrm{P}}\left(\mathrm{r}^{2}=0.23\right)$. Investigating the $\mathrm{Hg}_{\mathrm{D}}$ speciation, significant negative correlations were observed between DGM and $\mathrm{MMHg}_{D}\left(r^{2}=0.45\right.$; $[\mathrm{DGM}]_{\mathrm{pmol} \mathrm{I-1}}=-0.1\left[\mathrm{MMHg}_{\mathrm{D}}\right]_{\mathrm{pmol} \mathrm{L-1}}+0.35 ; \mathrm{Fig}$. 6), and DGM and $\mathrm{MMHg}_{\mathrm{D}} / \mathrm{HgT}_{\mathrm{D}}(\%)\left\{\mathrm{r}^{2}=0.61\right.$; [DGM]pmol L-1 = 1.1 [MMHg D/HgTD (\%)]-0.6\}. Observations such as these suggested either (i) a bacterial resistance to $\mathrm{Hg}$ through potential demethylation by the mer operon or (ii) that $\mathrm{MMHgD}$ production limits $\mathrm{Hg}$ availability with respect to reduction (Fig. 6). More unusual was the absence of significant correlation with HgRUNF (commonly considered as a precursor of DGM). The reduced light penetrability combined with high OM concentrations $(0.47 \mathrm{mmol}$ L-1 of TOC) and wide pool of reduced ligands $(0.7 \mu \mathrm{mol} L-1$ of $\Sigma \mathrm{H} 2 \mathrm{~S})$ may explain the lack of relationship. Hence, in this particular environment, the HgDSC may define the active fraction involved in the DGM formation process.

\subsection{The methylmercury redox cycle}

\subsubsection{Methylmercury partition and distribution}

The USE concentration of $\mathrm{MMHg}_{\mathrm{UNF}}$ averaged $3.7 \pm 1.0 \mathrm{pmol} \mathrm{L}^{-1}$ with $2.0 \pm 0.9 \mathrm{pmol} \mathrm{L}^{-1}$ as dissolved and $1.8 \pm 1.2$ (i.e. $220 \pm 130 \mathrm{pmol} \mathrm{g}^{-1}$ ) pmol $\mathrm{L}^{-1}$ as particulate (Tab. 2). In the dissolved phase, the methylated percentage $\left[\mathrm{MMHg}_{\mathrm{D}} / \mathrm{HgT}_{\mathrm{D}}(\%)\right]$ averaged $40 \pm 20 \%$ and reached $90 \%$ between Ker. and Bra. stations in the wet seasons. In the particulate phase, the methylated percentage $\left[\mathrm{MMHg}_{\mathrm{P}} / \mathrm{HgT}_{\mathrm{P}}\right.$ (\%)] averaged $40 \pm 20 \%$ and reached $97 \%$ between Bra. and Sin. stations in the dry seasons (Figs. 4 and 6). Regarding the $\log K_{d}(\mathrm{MMHg})$, calculated values, averaging $5.0 \pm 0.4$, were in the upper range of data available from the literature (e.g., Cai et al., 1999; Choe and Gill, 2001). Similar log partition coefficients were found in the Trinity River (USA) for colloidal (1 kDa-0.45 $\mu \mathrm{m})$ and truly dissolved $(<1$ $\mathrm{kDa}$ ) fractions (Choe and Gill, 2001). In the USE, MMHg and POC displayed a significant positive relationship with seasons $\left(r^{2}=0.61 ;\left[\mathrm{MMHg}_{\mathrm{D}}\right]_{\mathrm{pmol} \mathrm{L-1}}=180[\mathrm{POC}]_{\mathrm{mmol} \mathrm{L-1}}-8.8\right.$; Fig. 5). Since colloids primarily consist of finer particles and organic macromolecules that pass into the filtrate, we expected that colloidal and particulate phases shared a common pool of ligands (e.g. reduced sulfur and thiol moieties). This was supported by positive correlations between (i) $\mathrm{MMHg}_{\mathrm{D}}$ and the organic component of particles $\left(r^{2}=0.44 ;\left[\mathrm{MMHg}_{\mathrm{D}}\right]_{\mathrm{pmol} \mathrm{L}-1}=0.12[\mathrm{POC}]_{\mathrm{mmol} \text { g-1 }}-0.8\right.$, Fig. 5), and (ii) log partitions coefficients of $\mathrm{MMHg}$ and organic $\mathrm{C}$ (Figs. 5 and 6). Using the WHAM 6 program, we calculated that nearly $100 \%$ of the $\mathrm{MMHg}_{\mathrm{D}}$ in the USE was associated with colloidal OM.

$\mathrm{MMHg}_{\mathrm{uNF}}$ in the tributaries averaged $1.3 \pm 0.6 \mathrm{pmol} \mathrm{L}^{-1}$ of which $0.8 \pm 0.5$ and $0.4 \pm 0.3$ (i.e. $80 \pm 60$ pmol g${ }^{-1}$ ) pmol $\mathrm{L}^{-1}$ were $\mathrm{MMHg}_{\mathrm{D}}$ and $\mathrm{MMHg}_{\mathrm{p}}$, respectively. As a result, during the wet seasons, the tributaries contributed to the USE dilution with MMHg in the vicinity of Creek Kerenrock, Creek Venus and Creek Saulnier (Fig. 4). In the tributaries, low $\Sigma \mathrm{H}_{2} \mathrm{~S}$ concentrations coupled with high Eh values (> $350 \mathrm{mV}$ ) settled unfavorable conditions for $\mathrm{Hg}$ methylation. However, quantifiable $\mathrm{MMHg}$ concentrations highlighted the existence of diffuse sources. Main sources of MMHg consisted of the sandy sediments, the leaf litter and the biofilms. While the methylation rates were low in the sediments $\left(0.3 \pm 0.2 \% \mathrm{hr}^{-1}\right)$, higher values were determined in the surface litter $\left(1.4 \pm 0.4 \% \mathrm{hr}^{-1}\right)$ and the biofilms $\left(0.6 \pm 0.2 \% \mathrm{hr}^{-1}\right)$ (Mason pers. com.). The leaf litter and the biofilms from the tributaries consisted mainly of $\mathrm{OM}$ at different stages of humification (> $80 \%$ dry weight). Substrata such as these may 
have built up favorable methylating conditions through the microbial activity and the oxygen depletion associated with the OM mineralization. Besides, from the 2003/04 tailrace water monitoring, an inverse relationship was observed between $\mathrm{MMHg}_{\mathrm{UNF}}$ and the redox $\left(\mathrm{r}^{2}=0.56\right.$; $\left[\mathrm{MMHg}_{\mathrm{UNF}}\right]_{\mathrm{pmol}} \mathrm{L-1}=-$ $\left.0.03 \mathrm{Eh}_{\mathrm{mv}}+8.3\right)$. Hence, reductive conditions not only promote $\mathrm{Hg}$ methylation in the USE but also accompany the increase of $\mathrm{MMHg}_{\mathrm{UNF}}$ in the waters exported from the dam (Fig. 3). Thus, in wet seasons, we propose the occurrence of two opposite processes: (i) elevated MMHgunf exportations via the dam tailrace (up to $0.15 \mathrm{~mol} \mathrm{~d}^{-1}$ ) and (ii) localized dilution of concentrations by creeks inflows (above $80 \mathrm{~m}^{3} \mathrm{~s}^{-1}$ ).

\subsubsection{In situ methylmercury production}

A preliminary budget can be built up for MMHg in the USE using the measurements in the main water sources. The most striking conclusion concerning the 2003-2005 period was that USE exported $5.5 \pm$ $0.7 \mathrm{~kg} \mathrm{y}^{-1} \mathrm{MMHg}_{\text {unF }}$ (55\% as MMHg D $_{\mathrm{D}}$ ) while barely $3 \pm 1$ and $0.5 \pm 0.2 \mathrm{~kg} \mathrm{y}^{-1} \mathrm{MMHg}_{\text {unF }}$ ( 50 and $70 \%$ as $\mathrm{MMHg}_{\mathrm{D}}$ ) reach the USE via the Petit-Saut dam and the river-tributaries, respectively. Hence, in the USE, the average $\mathrm{Hg}$ methylation rate [calculated as the ratio of the annual produced amount of $\mathrm{MMHg}_{\mathrm{unF}}(2 \mathrm{~kg})$ and the reservoir exports of unmethylated $\left.\mathrm{Hg}(13 \mathrm{~kg})\right]$ was $0.3-0.7 \% \mathrm{hr}^{-1}$. Despite uncertainties surrounding these figures, there is a strong suggestion that a large quantity of $\mathrm{MMHg}$ was produced in the USE itself.

Micromolar $\Sigma \mathrm{H}_{2} \mathrm{~S}$ concentrations $\left(0.7 \pm 0.5 \mu \mathrm{mol} \mathrm{L}^{-1}\right)$ and a reasonable balance between $\mathrm{O}_{2}$ and $\mathrm{MMHg}_{\mathrm{D}}$ levels $\left(\mathrm{r}^{2}=0.47\right.$; $\left.\left[\mathrm{MMHg}_{\mathrm{D}}\right]_{\text {pmol L-1 }}=15\left[\mathrm{O}_{2}\right]_{\mathrm{mmol} \mathrm{L}-1}\right)$ supported the USE in situ Hg methylation (Fig. 6). The role of $\mathrm{O}_{2}$ was dual. On the one hand, water oxygenation favors the $\Sigma \mathrm{H}_{2} \mathrm{~S}$ oxidation to $\mathrm{SO}_{4}$ (SRB substratum). Between Tail. and Ven. sampling stations, $\mathrm{SO}_{4}$ increased from 6 to $16 \mu \mathrm{mol} \mathrm{\textrm {L } ^ { - }}$ ${ }^{1}$ while $\Sigma \mathrm{H}_{2} \mathrm{~S}$ decreased $\left(\mathrm{r}^{2}=0.55\right.$; $\left.\left[\mathrm{SO}_{4}\right]_{\mu \mathrm{mol} L-1}=-3\left[\Sigma \mathrm{H}_{2} \mathrm{~S}\right]_{\mu \mathrm{mol} L-1}+14\right)$. On the other hand, an excess of oxygenation inhibits the SRB activity to the benefits of oxygen metabolizing bacteria (e.g., $\mathrm{Fe}^{\prime \prime}$, $\Sigma \mathrm{H}_{2} \mathrm{~S}, \mathrm{CH}_{4}$, oxidizers; Dumestre et al., 2001). The $\mathrm{O}_{2}$ levels up to saturation (\%) and the $\mathrm{MMHg}_{\mathrm{D}} / \mathrm{HgT}_{\mathrm{D}}$ (\%) (a proxy of the local production of $\mathrm{MMHg}_{\mathrm{D}}$, Benoit et al., 2001, 2003) displayed an inverse evolution $\left[\mathrm{r}^{2}=0.37 ; \mathrm{MMHg}_{\mathrm{D}} / \mathrm{HgT}_{\mathrm{D}}(\%)=-1.2 \mathrm{O}_{2}(\%)+100\right]$. Hence, low $\mathrm{O}_{2}$ depicted the sites of moderate $\mathrm{MMHg}_{\mathrm{D}}$ concentrations but intense endogenous $\mathrm{Hg}$ methylation (such as Deg. station).

The hypothesis of in situ $\mathrm{Hg}$ methylation emerged from: (i) the rapid increase of MMHgunF and $\mathrm{MMHg}_{\mathrm{D}}$ concentrations between Tail. and Pas. stations (Tab. 3 and Fig. 4) and (ii) the parallel study of $\Sigma \mathrm{H}_{2} \mathrm{~S}$ concentrations and $\mathrm{MMHg}_{\mathrm{D}} / \mathrm{HgT}_{\mathrm{D}}(\%)$ in the USE. On the one hand, between Tail. and Pas. stations, the average $\mathrm{Hg}$ methylation rate [calculated as the ratio of the annual produced amount of MMHgunF (approximately $1 \mathrm{~kg}$ ) and the reservoir export of unmethylated $\mathrm{Hg}(13 \mathrm{~kg})]$ was $10-15 \% \mathrm{hr}^{-1}$ and reached $27 \% \mathrm{hr}^{-1}$ in the dissolved phase. Comparatively, the rate of MMHg release due to the oxidative dissolution of AVS [calculated from the measured decrease of $\mathrm{MMHg}_{\mathrm{p}}$, of $100 \pm 70 \mathrm{pmol} \mathrm{g}^{-1}$ ] averaged $9 \pm 5 \% \mathrm{hr}^{-1}$ (i.e. $0.6 \pm 3 \mathrm{~kg} \mathrm{yr}^{-1}$ ). This represented $90 \pm 30 \%$ of the observed $\mathrm{MMHg}_{\mathrm{D}}$ produced in the immediate vicinity of the artificial aeration system and $50 \pm 30 \%$ of the $\mathrm{MMHg}_{\mathrm{D}}$ produced in the USE. On the other hand, in the downstream of the Pas. station, the bulge shape of the $\mathrm{MMHg}_{\mathrm{D}} / \mathrm{HgT}_{\mathrm{D}}$ (\%) vs. $\Sigma \mathrm{H}_{2} \mathrm{~S}$ relationship suggested an optimum $\Sigma \mathrm{H}_{2} \mathrm{~S}$ concentration for $\mathrm{Hg}$ methylation (Fig. 6). The sites of low and intermediate $\Sigma \mathrm{H}_{2} \mathrm{~S}$ concentrations $\left(<1 \mu \mathrm{mol} \mathrm{L}^{-1}\right)$ exhibited analogous variations of both parameters $\left\{\mathrm{r}^{2}=0.70 ; \mathrm{MMHg}_{\mathrm{D}} / \mathrm{HgT}_{\mathrm{D}}(\%)=100\left[\mathrm{LH}_{2} \mathrm{~S}\right]_{\mu \mathrm{mol}} \mathrm{L}^{-1}+10\right\}$. This was consistent with the hypothesis of neutral $\mathrm{Hg}-\mathrm{S}$ complexes controlling the bioavailability of inorganic mercury towards SRB (Benoit et al., 1999, 2003). On the contrary, more sulfidic environments $\left(>1 \mu \mathrm{mol} \mathrm{L} \mathrm{L}^{-1}\right.$ ) exhibited inverse variations between $\mathrm{MMHg}_{\mathrm{D}} / \mathrm{HgT}_{\mathrm{D}}(\%)$ and $\Sigma \mathrm{H}_{2} \mathrm{~S}$ concentrations $\left\{\mathrm{r}^{2}=0.76 ; \mathrm{MMHg}_{\mathrm{D}} / \mathrm{HgT}_{\mathrm{D}}(\%)=-50\left[\Sigma \mathrm{H}_{2} \mathrm{~S}\right]_{\mu m o l} \mathrm{~L}-1+120\right\}$ (Fig. 6). This would account for a lessening in $\mathrm{Hg}$ bioavailability due to formation of ionic $\mathrm{Hg}-\mathrm{S}$ complexes [ $\mathrm{HgS}(\mathrm{SH})^{-}, \mathrm{HgS}_{2}{ }^{2-}$ etc.] and/or precipitation of inorganic $\mathrm{Hg}$ as cinnabar. A balance between water oxygenation which controls SRB activity through production of sulfates and $\Sigma \mathrm{H}_{2} \mathrm{~S}$ level that governs $\mathrm{Hg}$ bioavailability played a large role in the local production of $\mathrm{MMHg}$.

Lowering $\mathrm{pH}$ contributed to decrease the log partition coefficient of $\mathrm{HgT}\left[\mathrm{r}^{2}=0.33 ; \log \mathrm{K}_{\mathrm{d}}(\mathrm{HgT})=0.5 \mathrm{pH}\right.$ $+2.0]$ and increase that of $\mathrm{MMHg}\left[\mathrm{r}^{2}=0.46 ; \log K_{\mathrm{d}}(\mathrm{MMHg})=-0.9 \mathrm{pH}+10.0\right]$ (Fig. 6). On the one hand, water acidification would promote the $\mathrm{HgT}_{\mathrm{P}}$ mobilization towards the dissolved phase (e.g. via acidic dissolution of AVS and/or Fe oxyhydroxides). On the other hand, according to the Benoit et al. (2003) formulation:

$$
\mathrm{RSHg}^{+}+\mathrm{H}_{2} \mathrm{O}+\mathrm{HS}^{-}=\mathrm{HgS}^{0}+\mathrm{RSH}+\mathrm{H}^{+}
$$


increasing $\left[\mathrm{H}^{+}\right]$leads to decreasing $\left[\mathrm{HS}^{-}\right]$, and as a result, $\mathrm{HgS}^{0}$ (the hypothetical substratum of methylation) will decrease relative to $\mathrm{RSHg}^{+}$i.e., methylation rate and $\mathrm{MMHg}_{\mathrm{D}}$ should at length decrease. This consideration was supported by a positive correlation between $\mathrm{pH}$ and $\mathrm{MMHg}_{\mathrm{D}} / \mathrm{HgT}_{\mathrm{D}}$ (\%) $\left[\mathrm{r}^{2}=0.42 ; \mathrm{MMHg}_{\mathrm{D}} / \mathrm{HgT}_{\mathrm{D}}(\%)=60 \mathrm{pH}-300\right]$. Hence, a reasonable balance between the $\mathrm{Hg}$ mobilization from the particulate phase (which increases with $\left[\mathrm{H}^{+}\right]$) and the $\mathrm{HgS}^{0}$ production in the dissolved phase (which decreases with $\left[\mathrm{H}^{+}\right]$) also determined the production of $\mathrm{MMHg}$. In conclusion, slightly acidic waters, as in the USE, provide favorable conditions for $\mathrm{MMHg}$ production.

\subsubsection{Methylmercury trapping and mobilization}

According to Benoit et al. (2003), the complexation of MMHg to OM or inorganic sulfide phases are comparable since both involve interactions with thiols or other reduced $\mathrm{S}$ species. The same authors proposed that lowering $\mathrm{pH}$ would favor the $\mathrm{MMHg}$ association with particles:

$$
\mathrm{RS}-\mathrm{H}+\mathrm{CH}_{3} \mathrm{Hg}(\mathrm{OH})=\mathrm{RS}-\mathrm{HgCH}_{3}+\mathrm{H}_{2} \mathrm{O}
$$

This was testified with our data: $\mathrm{MMHg}_{\mathrm{p}}$ concentrations increased with decreasing $\mathrm{pH}\left(\mathrm{r}^{2}=0.61\right.$; $\left.\left[\mathrm{MMHg}_{\mathrm{P}}\right]_{\mathrm{pmol}} \mathrm{g-1}=-280 \mathrm{pH}+1800\right)$. A marked inverse relationship $\left(\mathrm{r}^{2}=0.60\right.$, Fig. 6$)$ was also observed between $\mathrm{MMHg}_{\mathrm{P}} / \mathrm{HgT}_{\mathrm{P}}(\%)$ and $\mathrm{MMHg}_{\mathrm{D}} / \mathrm{HgT}_{\mathrm{D}}(\%)$. We thus concluded to a high mobility of methylated $\mathrm{Hg}$ species between the dissolved and particulate phases along the USE. Acid-base mechanisms and $\Sigma \mathrm{H}_{2} \mathrm{~S}$ levels seemingly drove the MMHg phase changes. Maxima of $\mathrm{MMHg}_{\mathrm{p}} / \mathrm{Hg}_{\mathrm{P}}(\%)$ corresponded to the most acidic and oxidized waters (such as Ker. or Ven. stations) whereas slightly acidic and sulfidic milieus displayed among highest $\mathrm{MMHg}_{\mathrm{D}} / \mathrm{HgT}_{\mathrm{D}}$ (\%) (like Pas. or Deg. stations). Overall, changes in $\mathrm{MMHg}$ binding resulted in a $5 \%$ increase of $\mathrm{MMHg}_{\mathrm{P}} / \mathrm{HgT}_{\mathrm{P}}(\%)$ per $0.1 \mathrm{pH}$ unit of water acidification.

Trapping of $\mathrm{MMHg}_{\mathrm{D}}$ and mobilization of $\mathrm{MMHg}_{\mathrm{p}}$ constituted dynamic processes that occurred simultaneously in the Sinnamary Estuary. To illustrate (Fig. 5), below $10 \mu \mathrm{mol} \mathrm{L}^{-1}$, the distributions of $\mathrm{FeT}_{\mathrm{D}}$ and $\mathrm{MMHg}_{\mathrm{D}}$ correlated positively $\left(\mathrm{r}^{2}=0.65\right.$; $\left.\left[\mathrm{MMHg}_{\mathrm{D}}\right]_{\text {pmol }} \mathrm{L}^{-1}=0.24\left[\mathrm{FeT}_{\mathrm{D}}\right]_{\mu \mathrm{mol}} \mathrm{L}^{-1}+0.73\right)$. Conversely, above that limit, $\mathrm{FeT}_{\mathrm{D}}$ and $\mathrm{MMHg}_{\mathrm{D}}$ correlated negatively $\left(\mathrm{r}^{2}=0.54 ;\left[\mathrm{MMHg}_{\mathrm{D}}\right]_{\mathrm{pmol}} \mathrm{L}^{-1}=-0.12\right.$ $\left.\left[F e T_{D}\right]_{\mu m o l} L^{-1}+4.2\right)$. An inverted pattern was observed when plotting the $\mathrm{FeT}_{\mathrm{D}}$ vs. $\mathrm{MMHg}_{\mathrm{P}}$. Thus, $\mathrm{MMHg}_{\mathrm{p}}$ mobilization (e.g. AVS dissolution) dominated in the vicinity of the Petit-Saut dam while $\mathrm{MMHg}_{\mathrm{D}}$ trapping (e.g. precipitation of Fe oxyhydroxides) prevailed further along the way to the Atlantic Ocean. Applying the model described in Section 2.3. to $\mathrm{MMHg}_{\mathrm{D}}$ and $\mathrm{MMHg}_{\mathrm{P}} \mathrm{Vs}$. $\mathrm{FeT}_{\mathrm{D}}$ relationships, we calculated that (i) $130 \pm 30 \mathrm{nmol}$ of $\mathrm{MMHg}_{\mathrm{P}}$ are mobilized per mol of discharged $\mathrm{FeT}_{\mathrm{D}}$ and (ii) nearly $250 \pm 50 \mathrm{nmol}$ of $\mathrm{MMHg}_{\mathrm{D}}$ are scavenged per mol of oxidized $\mathrm{FeT}_{\mathrm{D}}$. Scaled to the 7000 tons of $\mathrm{FeT}_{\mathrm{D}}$ discharged downstream of the dam, $3.0 \pm 0.7 \mathrm{~kg} \mathrm{y}^{-1}$ of $\mathrm{MMHg}_{\mathrm{P}}$ were transferred to the dissolved phase while close to $4.9 \pm 0.9 \mathrm{~kg} \mathrm{y}^{-1}$ were subsequently scavenged on authigenic particles. If we assume that the excess of scavenging (close to $1.9 \mathrm{~kg}$ ) originated mainly from in situ methylation processes, then at least $30-50 \%$ of the downstream MMHgunf amount $(5.5 \pm 0.7 \mathrm{~kg})$ was endogenically produced.

\section{Concluding Remarks}

This is the first investigation of the methylation potential of a tropical estuary that undergoes hypolimnetic discharges was probed. Extensive field measurements of $\mathrm{Hg}$ partitioning and speciation as well as long-term concentration monitoring of the dissolved and particulate phases of the Sinnamary Estuary indicated that methylation conformed to Benoit's neutral complex theory. Accordingly, the balance between sulfides concentration, which governs $\mathrm{Hg}$ bioavailability, and water oxygenation, which controls SRB activity through production of sulfates, determines which stations have high $\mathrm{MMHg}_{\mathrm{D}}$ concentrations. Besides, acid-base mechanisms, along with Fe cycling, had a significant impact on $\mathrm{MMHg}$ partitioning between phases.

To conclude, the Sinnamary Estuary constituted a chemical reactor with respect to $\mathrm{Hg}$ methylation and reduction. Atmospheric $\mathrm{Hg}$ evasion reflected (i) the DGM export from the dam, (ii) the net balance between the reduction and the oxidation processes and (iii) the $\mathrm{Hg}^{\circ}$ complexation with POC. Hence, the USE production of $\mathrm{MMHg}$ exceeded the amount of $\mathrm{Hg}$ transferred to the atmosphere by one order of magnitude: $2.0 \pm 1.5$ and $0.2 \pm 0.1 \mathrm{~kg} \mathrm{y}^{-1}$, respectively. 


\section{Acknowledgements}

We acknowledge $\mathrm{Y}$. Dominique for his suggestions and technical assistance during in situ campaigns and laboratory tasks. We also thank B. Burban, C. Reynouard, P. Cerdan, V. Horeau, R. Aboïkoni, L. Guillemet and R. Vigouroux for their participation and facilitation to sampling and analyses. This work has been financially supported by CNRS (Conseil National de la Recherche Scientifique) and EDF (Electricité de France) grant $N^{\circ}$ F01381/0.B. This manuscript also benefited from thorough reviews by three anonymous reviewers.

\section{References}

Alberts J. J., Schindler J. E., Miller R. W. and Nutter D. E. (1974) Elemental mercury evolution mediated by humic acid. Science 184, 895-897.

ALLARD B. and ARSENIE L. (1991) Abiotic reduction of mercury by humic substances in aquatic system. An important process for the mercury cycle. Water Air Soil Pollut. 56, 457-464.

Amouroux J. M. (2003) Genèse et devenir des mangroves. L'exemple de la Guyane. Cycles de conférences 2002 / 2003-Perspectives: Quel avenir pour l'Homme?

Amyot M., Mierle G., Lean D. and McQueen D. J. (1997) Effect of solar radiation on the formation of dissolved gaseous mercury in temperate lakes. Geochim. Cosmochim. Acta 61, 975-987.

BAEYENS W. and LEERMAKERS M. (1998) Elemental mercury concentrations and formation rates in the Scheldt estuary and the North Sea. Mar. Chem. 60, 257-266

BECKETT R. and. LE N. P. (1990) The role or organic matter and ionic composition in determining the surface charge of suspended particles in natural waters. Colloid. Surface. 44, 35-49.

BENOIT J. M., GILMOUR C. C., HEYES A., MASON R. P. and MILLER C. L. (2003) Geochemical and biological controls over mercury production and degradation in aquatic systems. ACS Sym. Ser. 835, 262-297.

BENOIT J. M., MASON R. P., GILMOUR C. C. and AIKEN G. R. (2001) Constants for mercury binding by dissolved organic matter isolates from the Florida Everglades. Geochim. Cosmochim. Acta 65, 4445-4451.

BENOIT J. M., GILMOUR C. C., MASON R. P. and HEYES A. (1999) Sulfide Controls on Mercury Speciation and Bioavailability to Methylating Bacteria in Sediment Pore Waters. Environ. Sci. Technol. 33,. 951-957.

Benoit J. M., Gilmour C. C., Mason R. P., Riedel G. S. and Riedel G. F. (1998) Behavior of mercury in the Patuxent River estuary. Biogeochem. 40, 249-265.

BISINOTI M. C. and JARDIM W. F. (2005) Production of organic mercury from $\mathrm{Hg}^{0}$ : experiments using microcosms. J. Braz. Chem. Soc. 14, 244-248.

BLOOM N. S. and EFFLER S. W. (1990) Seasonal variability in the mercury speciation of Onondaga Lake (New York). Water Air Soil Pollut. 53, 25-265.

BLOOM N. S. (1989) Determination of picogram levels of methylmercury by aqueous phase ethylation followed by cryogenic gas chromatography with cold vapour atomic fluorescence detection. Can. J. Fish. Aquat. Sci. 46, 1131-1140.

BLOOM N. S. and FITZGERALD W. F. (1988) Determination of volatile mercury species at the picogram level by low-temperature gas chromatography with cold-vapour atomic fluorescence detection. Anal. Chim. Acta 208, 151-161.

Boughriet A., Ouddane B., Fischer J. C., Wartel M. and Leman G. (1992) Variability of dissolved Mn and $\mathrm{Zn}$ in the Seine estuary and chemical speciation of these metals in suspended matter. Water Res. 26, 1359-1378.

Boyle E. A., Edmond J. M. and Sholkovitz E. R. (1977) The mechanism or iron removal in estuaries. Geochim. Cosmochim. Acta, 41, 1313-132.

BUfFLE J. (1988) Complexation reactions in aquatic systems, Ellis Horwood Ltd.

CAI Y., JAFFÉ R. I. and JONES R. D. (1999) Interactions between dissolved organic carbon and mercury species in surface waters of the Florida Everglades. App. Geochem. 14, 395-407. 
CHOE K-Y. and GILL G. A. (2001) Isolation of colloidal monomethyl mercury in natural waters using cross-flow ultrafiltration techniques. Mar. Chem. 76, 305-318.

CHOI S. C., CHASE T. J. and BARTHA R. (1994) Metabolic pathways leading to mercury methylation in Desulfovibrio desulfuricans LS. Appl. Environ. Microbiol. 60, 4072-4077.

COMPEAU G. and BARTHA R. (1985) Sulfate reducing bacteria: principal methylators of $\mathrm{Hg}$ in anoxic estuarine sediments. Appl. Environ. Microbiol. 50, 498-502.

COMPEAU G. and BARTHA R. (1984) Methylation and demethylation of mercury under controlled redox, $\mathrm{pH}$ and salinity conditions. Appl. Environ. Microbiol. 48, 1203-1207.

COQUERY M., COSSA D. and SANJUAN J. (1997) Speciation and sorption of mercury in two macrotidal estuaries. Mar. Chem. 58, 213-227.

COSSA D., AVERTY B., BRETAUDEAU J. and SENARD A. S., (2003) Spéciation du mercure dissous dans les eaux marines. Méthodes d'analyse en milieu marin, Editions Ifremer 27 pp.; ISBN 2-84433125-4.

COSSA D., COQUERY M., NAKHLE K. and CLAISSE D. (2002) Dosage du mercure total et du monomethylmercure dans les organismes et les sédiments marins. Méthodes d'analyse en milieu marin, Editions Ifremer 27pp.; ISBN 2-84433-105-X.

COSSA D. and GOBEIL C. (2000) Mercury speciation in the lower St. Lawrence estuary. Can. J. Fish. Aquat. Sci. 57, 138-147.

COSSA D. and GOBEIL C. (1996) Speciation and mass balance of mercury in the lower Saint Laurent estuary and Saguenay Fjord (Canada). $4^{\text {th }}$ International Conference on Mercury as a Global Pollutant Book of Abstracts, Hamburg 458, 4-8.

DE JUNET A. (2004) Etude qualitative de la matière organique particulaire dans le réservoir de PetitSaut (Guyane Française) : Composition Isotopique $\left(\delta^{13} \mathrm{C}\right)$, élémentaire $(\mathrm{C} / \mathrm{N})$ et pigmentaire. Master report, Talence, $41 \mathrm{pp}$.

DUMESTRE J-F., EMILIO C. O., RAMON M. and PEDROS-ALIO C. (2001) Changes in bacterial assemblages in a equatorial river induced by water eutrophication of Petit Saut dam reservoir (French Guiana). Aquat. Microb. Ecol. 26, 209-221.

DYRSSEN D. and WEDBORg M. (1991) The sulphur-mercury(II) system in natural waters. Water Air Soil Pollut. 56, 507-519.

DZOMBAK D. A. and MOREL F. M. M. (1990) Surface complexation modeling Hydrous ferric oxide. New York John Wiley and Sons, $393 \mathrm{pp}$.

GILMOUR C. C., HENRY E. A. and MITCHELL R. (1992) Sulfate Stimulation of Mercury Methylation in Freshwater Sediments. Environ. Sci. Technol. 26, 2281-2287.

Goulet R. R., Holmes J., Page B., Poissant L., Siciliano S. D., Lean D. R. S., Wang F., Amyot M. and Tessier A. (2007) Mercury transformations and fluxes in sediments of a riverine wetland. Geochim. Cosmochim. Acta 71, 3393-3406.

GUIMARAES J. R. D., ROULET M., LUCOTTE M. and MERGLER, D. (2000a) Mercury methylation along a lake-forest transect in the Tapajós river floodplain, Brazilian Amazon: seasonal and vertical variations. Sci. Total Environ. 261, 91-98.

GUIMARAES J. R. D., MEILI M., HYLANDER L. D., SILVA E., ROULET M., MAURO J. B. N. and LEMOS R. A. (2000b) Mercury net methylation in five tropical flood plain regions of Brazil: high in the root zone of floating macrophyte mats but low in surface sediments and flooded soils. Sci. Total Environ. 261, 99-107.

Heyes A., Mason R. P., Kim E. H. and Sunderland E. (2006) Mercury methylation in estuaries: Insights from using measuring rates using stable mercury isotopes. Mar. Chem. 102, 134-147.

HOREAU V., RICHARD S. and CERDAN P. (1998) La qualité de l'eau et son incidence sur la biodiversité. L'exemple de la retenue de Petit Saut (Guyane française). JATBA, Rev. Ethnobiol. 40, 53-77.

Hsu-Kim H. and Sedlak D. L. (2005) Similarities between inorganic sulfide and the strong $\mathrm{Hg}(\mathrm{II})-$ complexing ligands in municipal wastewater effluent. Environ. Sci. Technol. 39, 4035-4041.

HYDRECO: Laboratory for biological and chemical monitoring and analysis on the Petit-Saut reservoir. http://hydreco.mediasfrance.org/hydreco/

International Commission on Large Dams (2003) World register of dams 2003. Paris, France: ICOLD

JACOBS L. A., KLEIN S. M. and HENRY E. A. (1995) Mercury cycling in the water column of a seasonally anoxic urban lake (Onondaga Lake, NY). Water Air Soil Pollut. 80, 1-4.

JENSEN S. and JERNELOV A. (1969) Biological methylation of mercury in aquatic organisms. Nature 223, 753-754.

KING J. K., SAUNDERS F. M., LEE R. F. and JAHNKE R. A. (1999) Coupling mercury methylation rates to sulfate reduction rates in marine sediments. Environ. Toxicol. Chem. 18, 1362-1369. 
Leermakers M., Galetti S., de Galan S., Brion N. and Baeyens W. (2001) Mercury in the Souther North Sea and Sheldt Estuary. Mar. Chem. 75, 229-248.

Liang L., Horvat M. and Bloom N. S. (1994) An improved speciation method for mercury by GC/CVAFS after aqueous phase ethylation and room temperature precollection. Talanta 41, 371-379.

Mantoura R. F. C., Dickson A. and Riley J. P. (1978) The complexation of metals with humic materials in natural waters. Estuar. Coast. Mar. Sci. 6, 387-408.

Mason R. P., Lawson N. M.,Lawrence A. L., Leaner J. J., Lee J. G. and Sheu G. -R. (1999) Mercury in the Chesapeake Bay. Mar. Chem. 65, 77-96.

Mason R. P., Fitzgerald W. F., Hurley J., Hanson A. K., Donaghay P. L. AND Sieburth J. M. (1993) Mercury biogeochemical cycling in a stratified estuary. Limnol. Oceanogr. 38, 1227-1241.

MERCK: Photometry and test kits (2001) Certificates of quality of Spectroquant $^{\circledR}$ test kits. http://www.merck.de/servlet/PB/menu/1169840/index.html

MOREL F. M. M., KRAEPIEL A. M. L. and AMYOT M. (1998) The chemical cycle and bioacculumation of mercury. Annu. Rev. Ecol. Syst. 29, 543-566.

Mota A. M., Cruz P., Vilhena C. and GonCalves M.L.S. (2005) Influence of the sediment on lead speciation in the Tagus estuary. Water Res. 39, 1451-1460.

MuResan B., Cossa D., Richard S. and Dominque Y. (2008) Mercury Cycling in a Tropical Artificial Reservoir: Monomethylmercury Production and Sources. App. Geochem. 23, 1101-1126.

Muresan B., Cossa D., Richard S., and Burbant B. (2007) Mercury speciation and exchanges at the air-water interface of a tropical artificial reservoir, French Guiana. Sci. Total Environ. 385, 132-145.

National Institute of Standards and Technology (2004) Critical stability constants of metal complexes database. NIST Standard Reference Database 46, U.S. Dept. Commerce, National Institute of Standard and Technology.

NRIAGU J. O. (1994) Mechanistic steps in the photoreduction of mercury in natural waters. Sci. Total Environ. 154, 1-8.

O'DRISCOLL N. J., SICILIANO S. D., PEAK D., CARIGNAN R. and LEAN D. R. S. (2006) The influence of forestry activity on the structure of dissolved organic matter in lakes: Implications for mercury photoreactions. Sci. Total Environ. 366, 880-893.

Parker J. L. and Bloom N. S. (2005) Preservation and storage techniques for low-level aqueous mercury speciation. Sci. Total Environ. 337, 253-263.

PARKS J. W., LUTZ A. and SUTTON J. A. (1989) Water column methylmercury in the Wabigoon/English River-Lake system: factors controlling concentrations, speciation, and net production. Can. J. Fish. Aquat. Sci. 46, 2184-2202.

PERETYAZHKO T., CHARLET L., MURESAN B., KAZIMIROV V. and COSSA D. (2006) Formation of dissolved gaseous mercury in a tropical lake (Petit-Saut reservoir, French Guiana). Sci. Total Environ. 364, 260-271.

Powell K. J., Brown P. L., Byrne R. H., Gajda T., Hefter G., Sjöberg S. and Wanner H. (2005) Chemical speciation of environmentally significant heavy metals with inorganic ligands. Part 1: the $\mathrm{Hg}^{2+}-\mathrm{Cl}^{-}, \mathrm{OH}^{-}, \mathrm{CO}_{3}{ }^{2-}, \mathrm{SO}_{4}{ }^{2-}, \mathrm{PO}_{4}{ }^{3-}$ aqueous systems, Pure Appl. Chem. 77, 739-800.

Ravichadran $\mathrm{m}$. (2004) Interactions between mercury and dissolved organic matter - a review. Chemosphere 55, 319-331.

RICHARD S., ARNOUX A. and CERDAN P. (1997) Evolution in physico-chemical water quality in the reservoir and downstream following the filling of Petit-Saut dam (French Guiana). Hydroecol. Appl. 9 $(1 / 2), 57-83$.

RODRIGUEZ R. C. M-D., TESSIER E., AMOUROUX D., GUYONEAUD R., DURAN R., CAUMETTE P. and DONARD O. F. X. (2004) Mercury methylation/demethylation and volatilization pathways in estuarine sediment slurries using species-specific enriched stable isotopes. Mar. Chem. 90, 107-123.

ROULET M., LUCOTTE M. and GUIMARAES J. R. D., (2000) Methylmercury in the water, seston and epiphyton of an Amazonian river and its floodplain, Tapajos river, Brazil. Sci. Total Environ. 261, 4359.

ROULET M., LUCOTTE M., CANUEL R., RHEAULT I., TRAN S. et al., (1998a) Distribution and partition of total mercury in waters of the Tapajós River Basin, Brazilian Amazon. Sci. Total Environ. 213, 203-211.

Rozan T. F., Lassman M. E., Ridge D. P. and Luther G. W. III (2000) Evidence for iron, copper and zinc complexation as multinuclear sulphide clusters in oxic rivers. Nature. 406, 879-8826.

SERGIO A. C-S., GUIMARAES J. R. D., MAURO J. B. N., MIRANDA M. R. and AZEVEDO M. F. O. S. (2006) Mercury methylation and bacterial activity associated to tropical phytoplankton Sci. Total Environ. 364, 188-199.

Sholkovitz E. R., Boyle E. A. and Price N. B. (1978) The removal of dissolved humic acids and iron during estuarine mixing. Earth and Planet. Sc. Lett. 40, 130-136. 
Stoichev T., Amouroux D., Monperrus M., Point D., Tessier E., Bareille G., and Donard O. F. X. (2006) Mercury in surface waters of a macrotidal urban estuary (River Adour, south-west France). Chem. Ecol. 22, 137-148.

STUMM W., KUMMERT R. and SIGG L. (1980) A ligand exchange model for the adsorption of inorganic and organic ligands at hydrous oxide interfaces. Croat. Chem. Acta 53, 291-312.

Sunderland E. M., Gobas F. A. P. C., Heyes A., Branfireun B. A., Bayerd A. K., Cranstone R. E. and Parsonse M. B. (2004) Speciation and bioavailability of mercury in well-mixed estuarine sediments. Mar. Chem. 90, 91-105.

Tipping E. (2007) Modelling the interactions of $\mathrm{Hg}$ (II) and methylmercury with humic substances using WHAM/Model VI. App. Geochem. 22, 1624-1635.

Tipping E. (2002) Cation Binding by Humic Substances, Cambridge University Press.

Van den Berg C. M. G. (1984) Determination of the complexing capacity and conditional stability constants of complexes of copper with natural organic ligands in seawater by cathodic stripping voltammetry of copper-catechol complex ions. Mar.Chem. 15, 1-18.

WATRAS, C. J., BLOOM N. S., HUDSON R. J. M., GHERINI S., MUNSON R., CLAAS S. A., MORRISON K. A., HURLEY J. P., WIENER J. G., FITZGERALD W. F., MASON R. P., VANDAL G., POWELL D., RADA R., RISLOVE L., WINFREY M., ELDER J., KRABBENHOFT D. P., ANDREN A. W., BABIARZ C., PORCELLA D. B. and HUCKABEE J. W. (1994) Sources and fates of mercury and methylmercury in Wisconsin lakes. Mercury as a Global Pollutant: Integration and Synthesis, 153-177. WESTALL J. C. (1987) Adsorption mechanisms in aquatic surface chemistry. Aquatic surface chemistry: chemical processes at the particle-water interface, 3-32.

Whalin L., Kim E.-H. and Mason R. P. (2007) Factors influencing the oxidation, reduction, methylation and demethylation of mercury species in coastal waters. Mar. Chem. 107, 278-294.

World Commission on Dams (2000) Dams and development; a new framework for decision-making. Earthscan Publications Ltd, London and Sterling, VA 


\begin{tabular}{|c|c|c|c|c|}
\hline CAMPAIGN & PERIOD & SEASON & SAMPLING STATION & ANALYSES \\
\hline MATOUTOU 1 & $03-04 / 2003$ & Short dry & Tailrace, USE & \multirow{5}{*}{$\begin{array}{l}\text { Ancillary } \\
\text { parameters: } \\
\text { pH, Eh, } \mathrm{O}_{2}, \mathrm{POC} \text {, } \\
\mathrm{DOC} \mathrm{SO}_{4}, \Sigma \mathrm{H}_{2} \mathrm{~S} \text {, } \\
\mathrm{FeT}_{\mathrm{D}} \text {. } \\
\text { Mercury } \\
\text { compounds: } \\
\mathrm{HgT}, \mathrm{HgR}, \mathrm{DGM} \text {, } \\
\text { MMHg. }\end{array}$} \\
\hline MATOUTOU 2 & $01-02 / 2004$ & Short wet & Tailrace, USE, tributaries & \\
\hline MATOUTOU 3 & 05-06/2004 & Long wet & Tailrace, USE, tributaries & \\
\hline MATOUTOU 4 & $11-12 / 2004$ & Long dry & Tailrace, USE, tributaries & \\
\hline MATOUTOU 5 & $02-03 / 2005$ & Short dry & Tailrace, USE, tributaries & \\
\hline
\end{tabular}

Tab. 1. Summary of the different periods and sampling sites associated to the Matoutou campaigns. The Upper Sinnamary Estuary (USE) covers the given in the last column. 


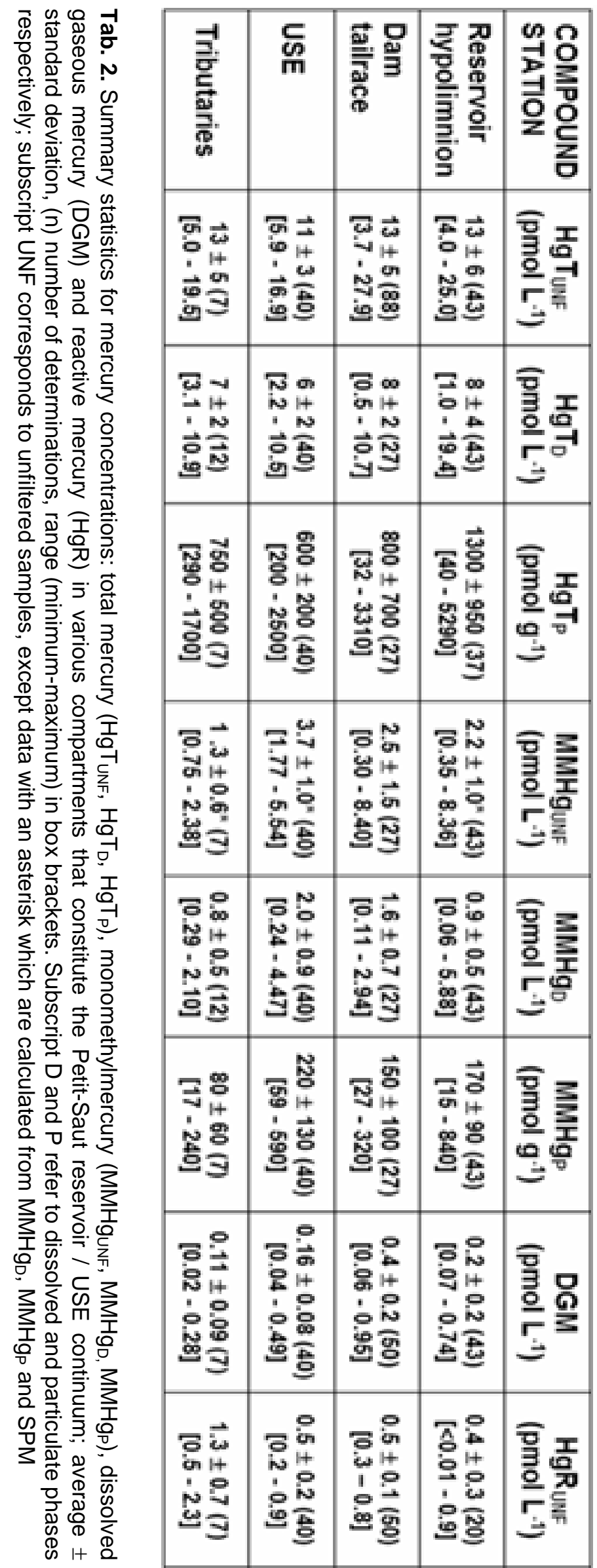




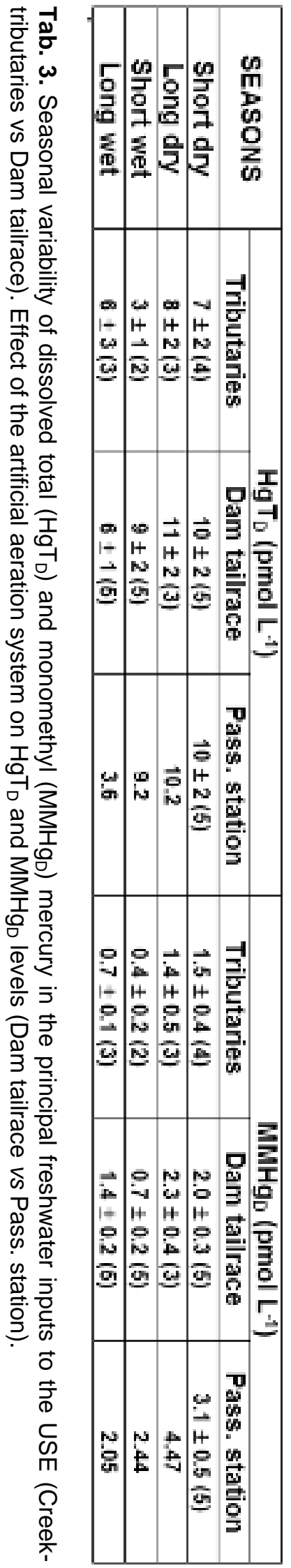




\section{Figures}

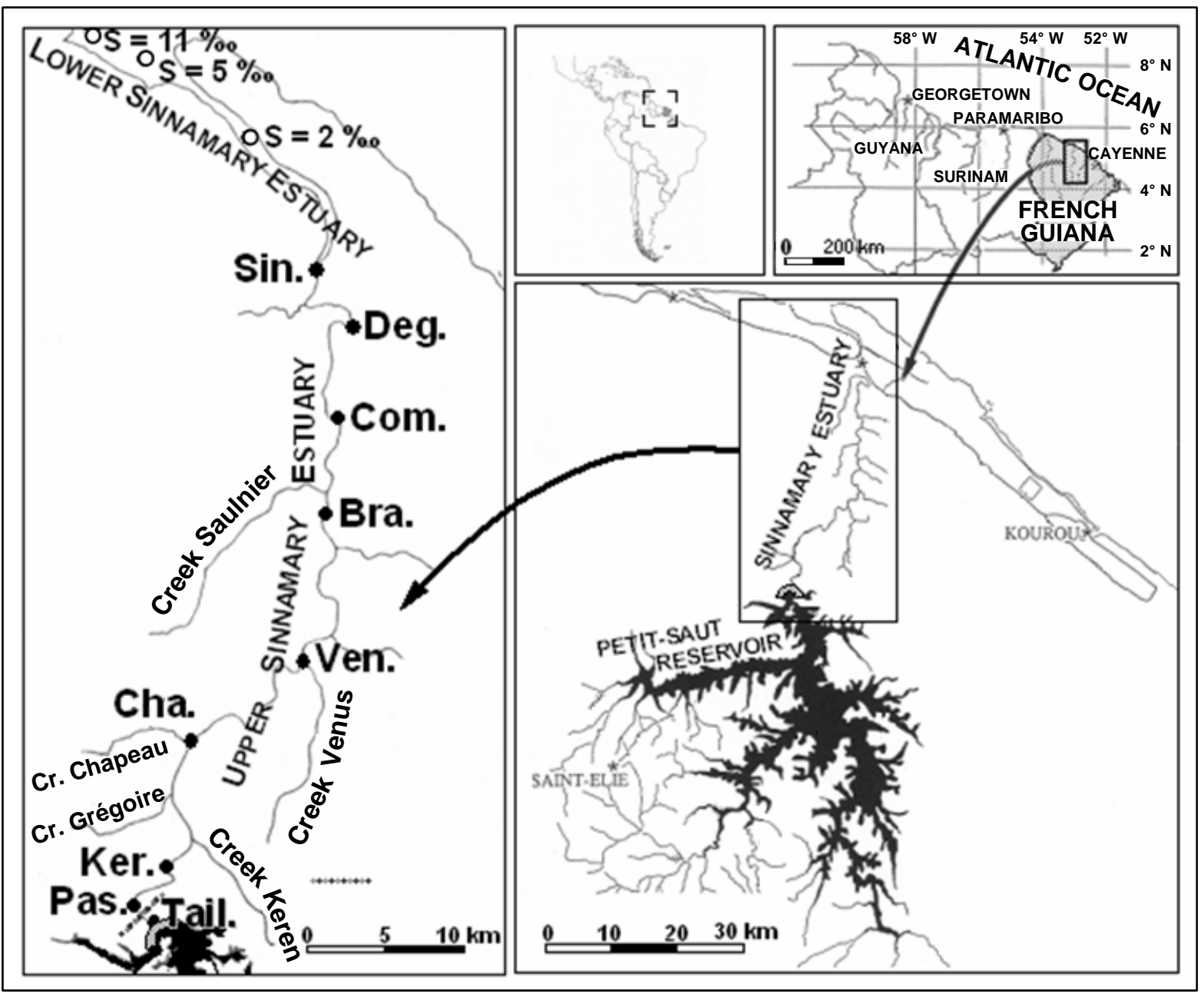

Fig. 1. The Sinnamary Estuary study area. Filled circles were sampled during Matoutou 1, 2, 3, 4 and 5 campaigns. The Kerenrock, Gregoire, Chapeau, Venus and Saulnier creek-tributaries to the USE were sampled during the Matoutou 2,3,4,5 sampling campaigns. The dam discharged waters were monitored (between March 2003 and December 2004) at the Tail. station. 


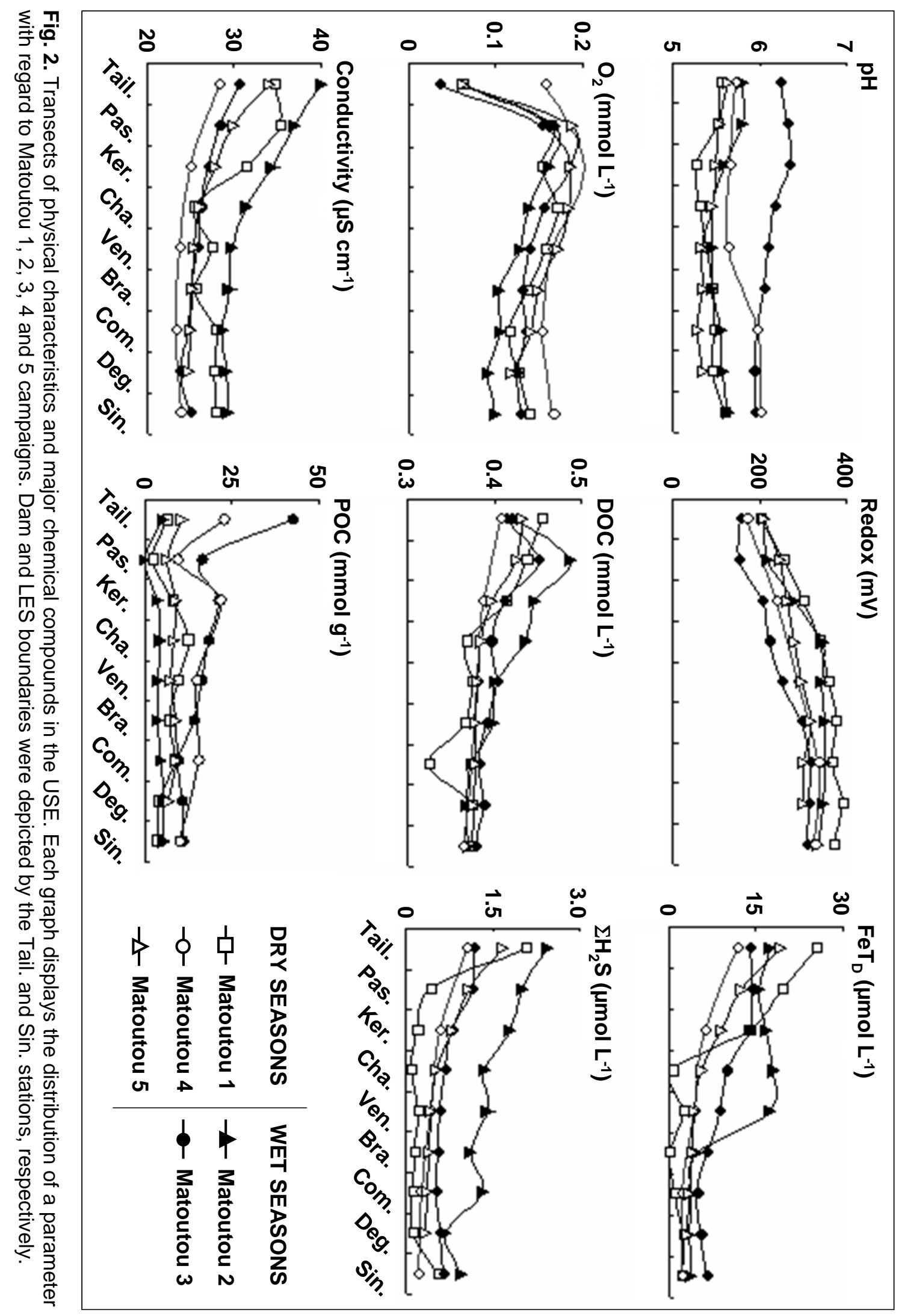




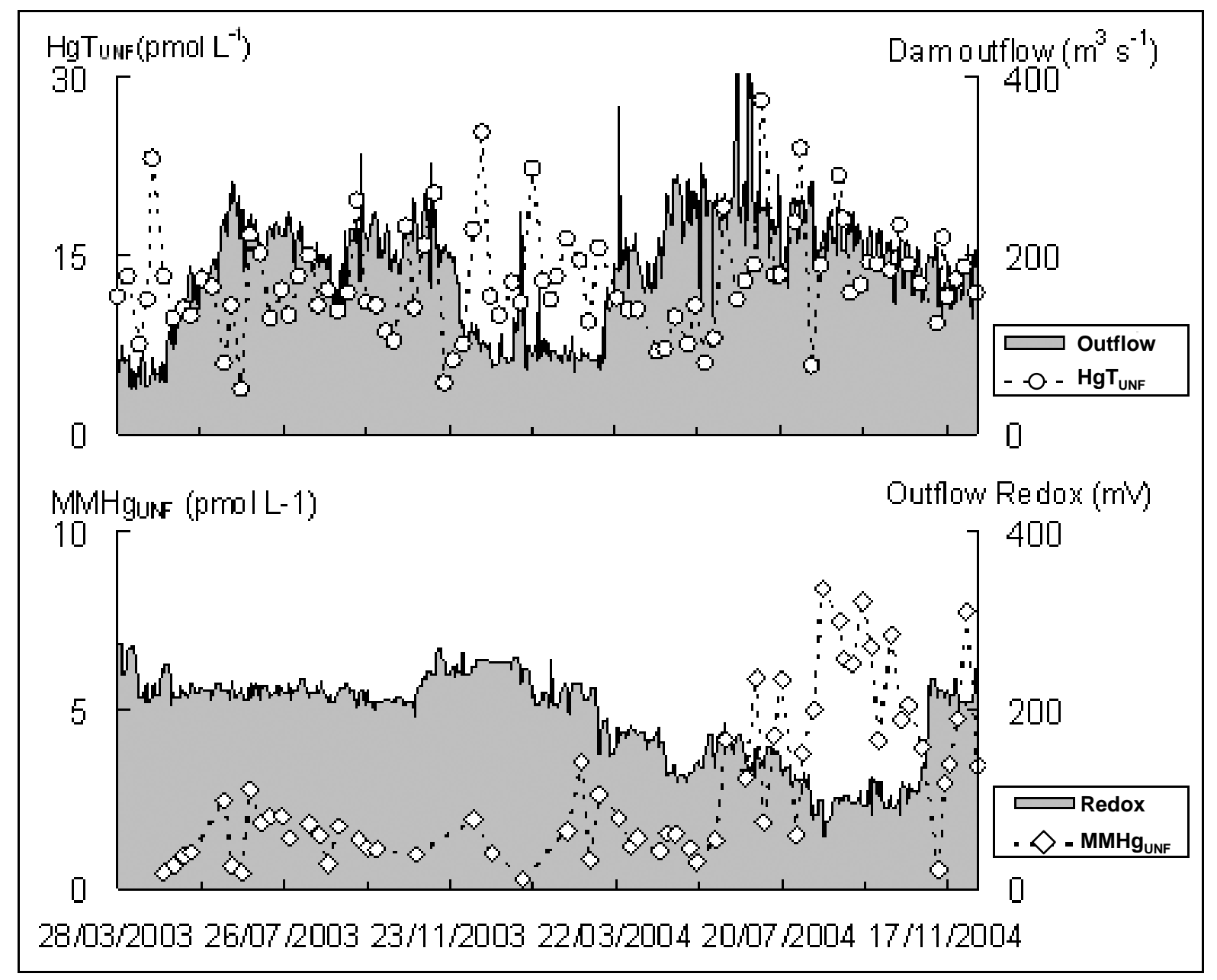

Fig. 3. Monitoring of unfiltered total ( $\mathrm{HgT}_{\mathrm{UNF}}$ ) and monomethyl (MMHguNF) mercury in exported waters downstream of the dam (Tail. station). Discharge flow and associated redox were daily recorded. Samples for $\mathrm{Hg}$ analyses were collected on a weekly basis. 


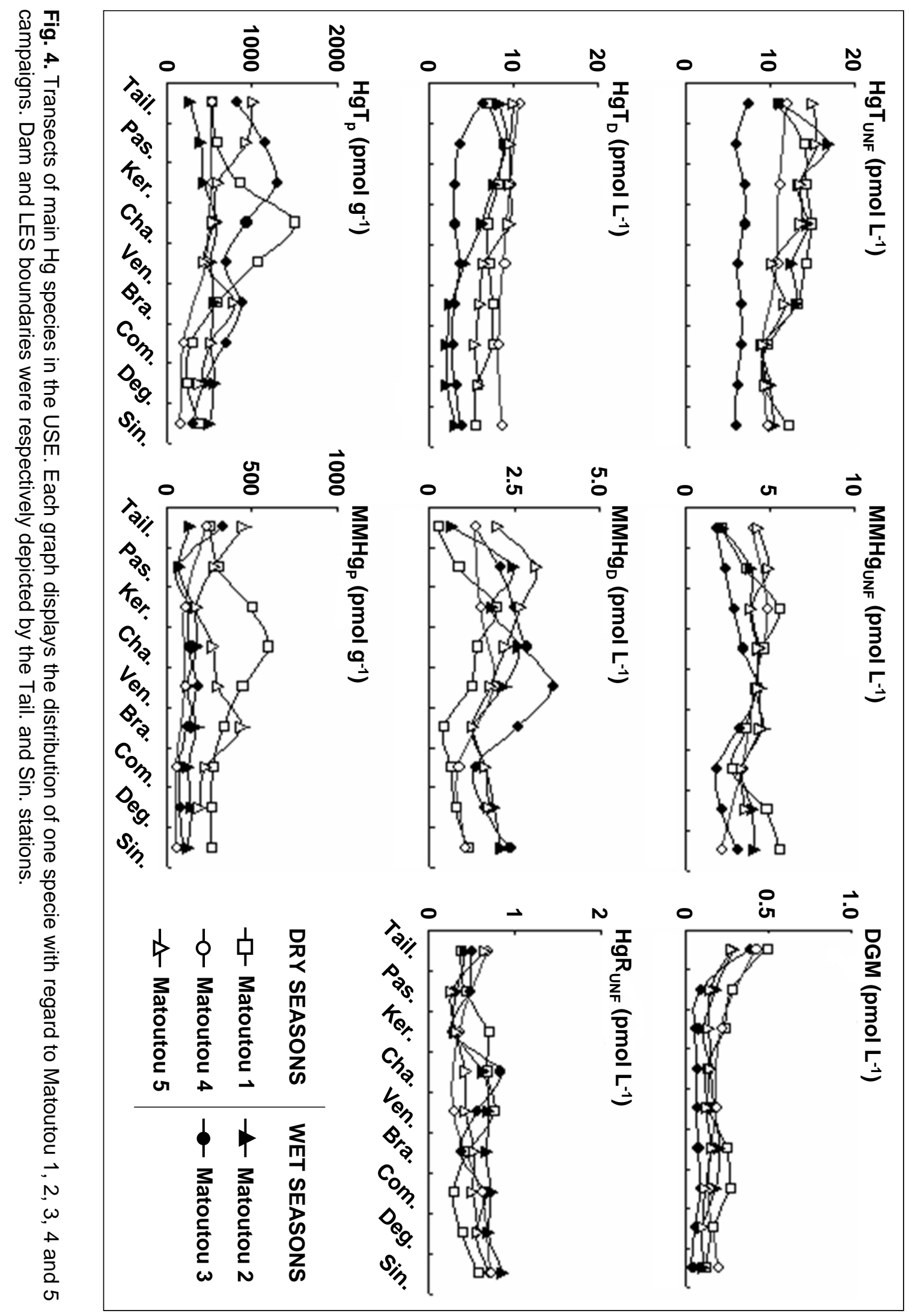




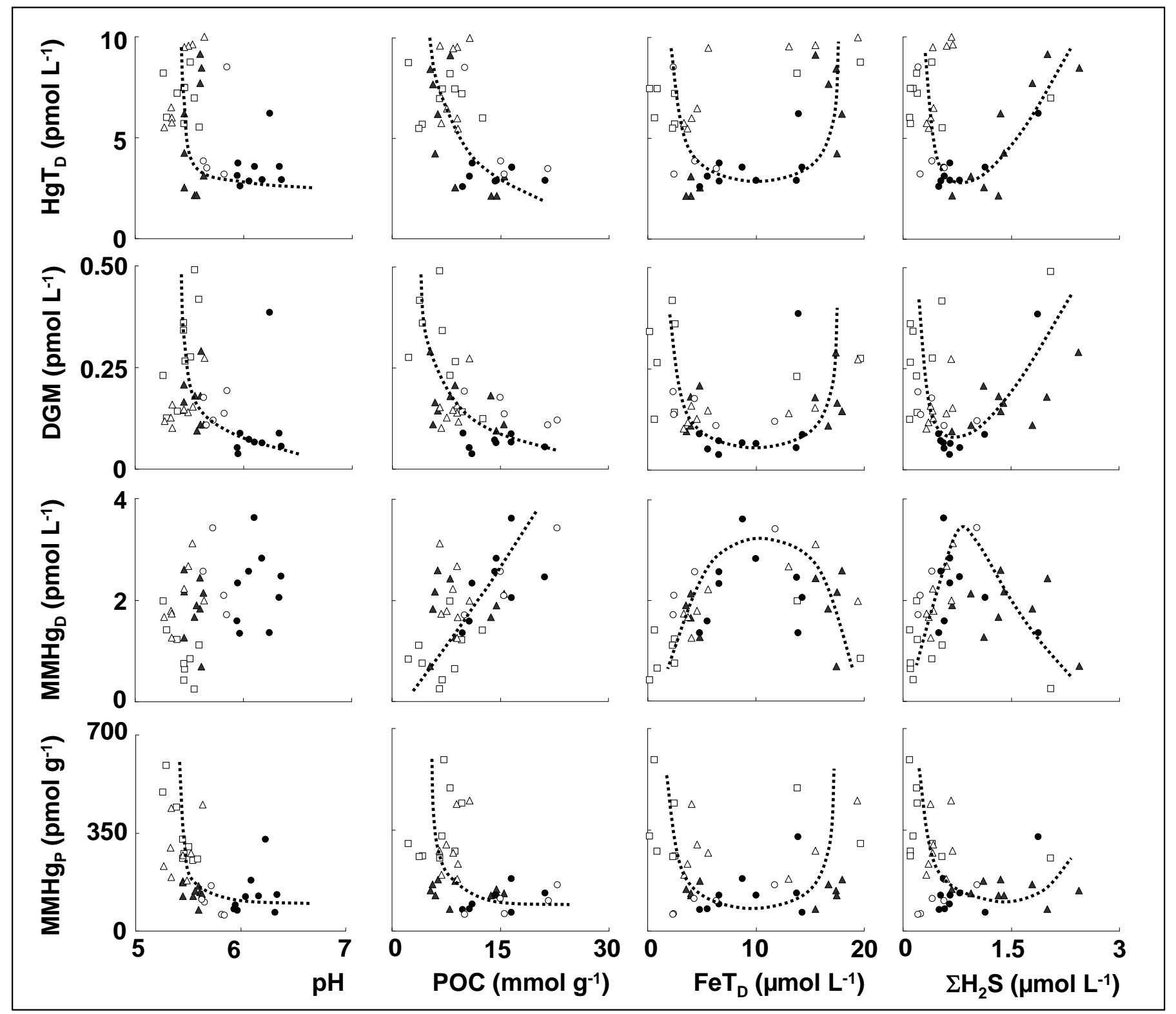

Fig. 5. Dissolved total mercury $\left(\mathrm{HgT}_{\mathrm{D}}\right)$, dissolved gaseous mercury (DGM), dissolved and particulate monomethylmercury $\left(\mathrm{MMHg}_{\mathrm{D}}\right)$ in relation to $\mathrm{pH}$, particulate organic carbon (POC), dissolved total iron (FeT $\left.\mathrm{T}_{\mathrm{D}}\right)$ and total sulfides $\left(\mathrm{\Sigma}_{2} \mathrm{~S}\right)$. Figures were plotted using the USE data from Matoutou $1(\square), 2(\boldsymbol{\Delta}), 3(\bullet), 4(\circ)$ and $5(\Delta)$ sampling campaigns. 


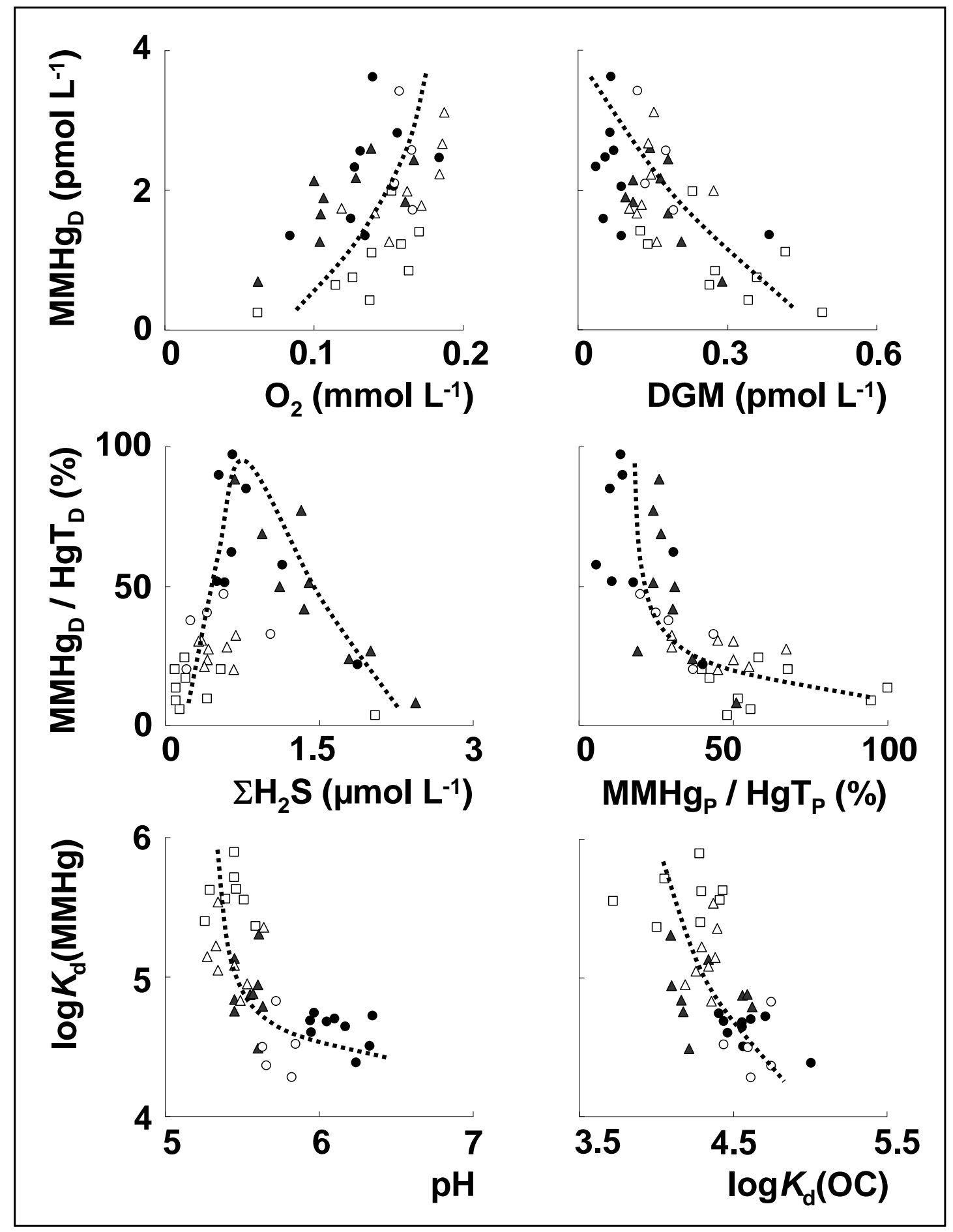

Fig. 6. Upper graphs: dissolved monomethylmercury $\left(\mathrm{MMHg}_{\mathrm{D}}\right)$ as a function of dissolved oxygen $\left(\mathrm{O}_{2}\right)$ and dissolved gaseous mercury (DGM). Middle graphs: percentage of dissolved monomethylmercury $\left[\mathrm{MMHg}_{\mathrm{D}} / \mathrm{HgT}_{\mathrm{D}}\right.$ (\%)] in relation to total sulfides $\left(\Sigma \mathrm{H}_{2} \mathrm{~S}\right)$ and percentage of particulate monomethylmercury $\left[\mathrm{MMHg}_{\mathrm{P}} / \mathrm{HgT}_{\mathrm{P}}(\%)\right]$. Lower graphs: Monomethylmercury log partition coefficient $\left[\log K_{\mathrm{d}}(\mathrm{MMHg}) ; K_{\mathrm{d}}(\mathrm{MMHg})=\mathrm{MMHg}_{\mathrm{P}} / \mathrm{MMHg}_{\mathrm{D}}\right]$ in relation to $\mathrm{pH}$ and organic carbon log partition coefficient $\left[\log K_{\mathrm{d}}(\mathrm{OC}) ; K_{\mathrm{d}}(\mathrm{OC})=\mathrm{POC} / \mathrm{DOC}\right]$. Figures were plotted using the USE data from Matoutou $1(\square), 2(\boldsymbol{\Delta}), 3(\bullet), 4(\circ)$ and $5(\Delta)$ sampling campaigns. 